\title{
SEVEN BROTHERS AND THE COSMIC HUNT: \\ EUROPEAN SKY IN THE PAST
}

Yuri Berezkin

\begin{abstract}
Reconstructing early European ideas about the night sky we should consider interpretations of the sky objects known across all Northern Hemisphere. Along with idiosyncratic cases, there are several concepts known from Africa to North America. The most widespread Eurasian - North American interpretation of Ursa Major is Seven men with Alkor as a dog or as a younger or weaker person (lad, girl, young woman). The cosmic hunt myth and the interpretation of Belt of Orion in its context probably also emerged somewhere in Central Eurasia and were brought from there to North America and to Africa.

In Eurasia those areas where main stars of Ursa Major were identified with seven men and where three stars of Orion were identified with three (rare: one) ungulate animals pierced with an arrow largely overlap but in America they are adjacent. Belt of Orion in context of Cosmic hunt is typical for the Southwest while the motif of Seven men is recorded across the Plains and rarely in the Northeast.

The interpretation of the Pleiades as a hen with chickens and of Orion as agricultural tools or harvesters, as a yoke and as a scale could not exist before Neolithic.
\end{abstract}

KEY WORDS: star lore, cosmic hunt myth, cosmonyms, Ursa Major, Orion, the Pleiades, ancient migrations

Present day European cosmonyms are borrowed from both Greek (directly or through Latin) and Arabic though some vernacular names like the English Big Dipper, Estonian Suur Vanker ("big cart") or Spanish Siete cabrillos ("seven kids", the Pleiades) are still in use. Traditional folklore, related to the night sky, included ideas of different origin and time depth. Since the 
Terminal Pleistocene, we can select several demographic and cultural processes that most probably influenced interpretations of celestial objects. Peopling of the formerly uninhabited territories of Northern and North Eastern Europe by groups of southern and probably also eastern origin; the coming of Near Eastern agriculturists and stock-breeders to the Balkans and then to Central Europe during the Neolithic Period; the Bronze Age technological revolution including the spread of wheeled vehicles; the incorporation of European cultures into the trans-Eurasian communication network ("world-system") since about the Roman period - all contributed to the spread of new ideas that both partly replaced the former ones and were combined with them.

\section{WORLD DISTRIBUTION OF STAR LORE}

Reconstruction of the cosmonymies of the distant past is possible thanks to irregular world distribution of ideas concerning particular objects of the night sky. A fact of crucial importance is the poorness of sky lore in subSaharan Africa that corresponds to the general scarcity of etiological motifs in African folklore. Missionaries and ethnographers unanimously reported the lack of interest in interpretation of the night sky in sub-Saharan Africa, and paragraphs on folk African astronomy are usually laconic (Dennett 1898: 7; Gottschilng 1905: 382; Hollis 1909: 100; Junod 1927: 308; Laman 1962: 65; Lindblom 1920: 335; MacDonald 1891: 128; Spieth 1906: 557-558; Talbot 1932: 344; Tessmann 1923: 152; 1934: 218-219; Werner 1912: 195). The most probable explanation is that cultural evolving, in the tropical African homeland of modern man, with its relatively monotonous natural habitat, was slow while the settling of unfamiliar landscapes and climates promoted all kinds of modifications in culture of people engaged in distant migrations. Alteration of arid and pluvial periods in Africa resulted in displacement of borders between desert, savannah and rain forest but hardly in the creation of new ecosystems to the south of Sahel. On the eve of the out-of-Africa migration human star lore was probably simple or did not exist at all and ideas about constellations only emerged later in the context of cultural traditions developed on other continents, while in Africa star lore only minimally developed. In the $19-20^{\text {th }}$ century the Pleiades in sub-Saharan Africa were the only stellar object that systematically attracted people's attention and it also seems that the Pleiades were understood as something apart from other constellations and in a way similar to the Sun and the Moon. A myth of Luba of Congo illustrates this view and according to interpretation the Sun, the Moon and the Pleia- 
des successfully sustained a test suggested by God while the man failed to do it. Because of this the Sun rises every day, the Moon every month, the Pleiades every year and the man dies forever (Abrahamsson 1951: 50).

Difference in the star lore, between sub-Saharan African and other traditions, concerns not so much the number of objects selected, which in some Eurasian and American traditions was not great, but the degree of development of the explanatory narratives. Besides the Pleiades, in subSaharan Africa the Milky Way, Belt of Orion, Venus, sometimes Sirius and Jupiter were also known (Nilsson 1920: 118-121). But even for those objects, the existence of which was recognized, no mythological interpretation was usually available. The Pleiades with their heliacal rise and fall were mostly interpreted as a marker for the beginning of the New Year and agricultural season (Hirschberg 1929) and position of the Milky Way also was placed in connection to alternation of the dry or wet seasons (Lagercrantz 1952). The practically complete lack of interpretations for Ursa Major in sub-Saharan Africa was not simply due to its poorer visibility in the low latitudes in comparison with more northern regions. Both the Bantu-speaking people of Congo and Tanzania and Mande-speaking people of Guinea are familiar with Ursa Major (Carreira 1947: 233; Mahieu 1973: 3, 6, 9; Werner 1912: 195) but do not feel much interest in it because circum-Polar constellations are not convenient for counting calendar time. Outside of sub-Saharan Africa, at the same latitude in Oceania and America, Ursa Major was well known (Eyzaguirre 1956: 92; Lehner 1931: 115; Magaña 1988: 11-12; Williamson 1933: 130) though for the Melanesians, Polynesians and Brazilian or Guiana Indians the Pleiades and Orion were more important.

Australian, Polynesian and Micronesian, on one side, and Northern and Central Eurasian and North American traditions, on the other, demonstrate elaborate and detailed knowledge of the star objects. Australian, Oceanic as well as South American views of the night sky are different from each other and from Eurasian and North American patterns and this is understandable considering the different views of the night sky in the Northern and Southern Hemispheres. Many Eurasian and North American patterns are, however, identical and this cannot be explained by objective factors alone, because too many minor details coincide (Berezkin 2008a). The existence of North American parallels for Eurasian patterns is highly important for dating the time of their spread. Because the last Siberian ancestors of the American Indians left their Asian homeland no later than 12-10,000 B.P. and the Eskimo ancestors ca. 5000 B.P., we receive terminus ante quem for cultural patterns shared by corresponding North American and Eurasian peoples. 


\section{URSA MAJOR AND ORION AS ALTERNATIVES}

Across all of the Northern Hemisphere three groups of stars occupy a privileged position in folk interpretations of the night sky, these being the Pleiades, Orion (mostly three of the stars in its Belt) and the seven stars of Ursa Major, often with the eighth one, Alkor, a small star near Mizar, which itself is in the middle of the handle of the Dipper.

My hypothesis is that star lore focusing on the interpretation of Ursa Major, and on the interpretation of Orion (alone or linked to the Pleiades), are two early systems originating in Eurasia. In North America, these systems did not emerge independently but were brought from Asia and the active interaction between them was a relatively recent innovation that began only when the peopling of America was mostly completed. This conclusion is based on the fact that in North America Orion and Ursa Major are well separated from each other in tales and typical for traditions of different culture areas.

In the night sky Ursa Major is far from Orion and both are relatively seldom well viewed together while Orion and the Pleiades are much nearer to each other. This is a probable reason why the Pleiades and Orion are often mentioned together in stories while there are few narratives in which both Ursa Major and Orion play a part. If these constellations are linked at all, it is either in those cases when something like an inventory of the night sky, as a whole, was produced or when a named star broke away from a particular constellation to which it was originally designated to and was applied to another one. A case of such a shift of names between stellar objects is, perhaps, in Afanasi Nikitin's description of spring constellations made during his travel to India (1468-1474). „Volosyni da Kola v zoriu voshli, a Los golovoyu stoit na vostok" ("the Pleiades and Orion have entered the sunrise and Elk stands with its head to the east"). „Elk" is a correct northern Russian name for Ursa Major but „Kola" ("a cart") is southern Russian name for Ursa Major that here was applied to Orion (Sviatski 1961: 117-118). According to the recently recorded Lamut story three hunters who pursue the mountain goat are identified with the Pleiades (Burykin 2001: 113, no. 22) though they „should be“ identified with the three stars of the Big Dipper's handle.

Regarding Ursa Major and the Pleiades, these constellations are never mentioned together in North America though they can occupy a similar position in the structure of particular tales (several persons turn either into Ursa Major or into the Pleiades). In Eurasian cosmonymy Ursa Major and the Pleiades are rather often associated in folktales. However, here 
one and the same story is almost always repeated: seven men identified with the stars of Ursa Major have got a girl that originally belonged to the Pleiades (Ancient Greek, Bulgarians, Kumyk, Nogai, Kazakh, Kirghiz, Altai, Tuvinians, Khakas, different Mongolian groups) (Abishev 1949: 12-14; Allen 1899: 446; Benningsen 1912: 55-57; Brudny \& Eshmambetov 1989: 373374; Butanayev 1975: 234-235; Diakonova 1976: 286; Gamzatov \& Dalgat 1991: 305; Holmberg 1927: 428; Mladenova 2005: 80; Nikonov 1980: 296; Potanin 1883: 200, 784, no. 35k; Sadalova 2002: 215-223, no. 22). These tales most probably developed from a unique prototype localized somewhere in the Southern Siberian - Central Asian region. In Hindu mythology the seven Pleiades are wives of seven wise men, identified with the stars of Ursa Major (Allen 1899: 404; Shrestha 1996: 12-13). This case can be also indirectly related to Central Asian - Southern Siberian tales and elaborated in the context of late literary tradition. Central Asian links for Hindu mythology are especially probable because the Hindu interpretation, not only of Ursa Major and the Pleiades but also of the Belt of Orion, (antelope or deer pierced with an arrow identified with Betelgeuse) coincides with the Turkic-Mongolian pattern (Temkin \& Erman 1982: 18, 238, no. 3; Vassilkov \& Neveleva 1987: 701).

Both in Eurasia and in North America the Cosmic Hunt motif is related to Ursa Major in northern forested areas, to the Pleiades and other objects (Cassiopeia and Gemini) in Northern Europe, Northernmost and Northeast Asia and American Arctic, and to Orion in more southern areas (American Southwest and Southern Siberia - Central Asia). The Turkic-Mongolian and the American South-Western versions of Cosmic Hunt, according to which three stars of Orion's Belt are three deer or antelopes and Betelgeuse or Orion's head is a hunter's arrow, are very similar and certainly historically related. Across the North American Plains and the Northeast Ursa Major is just as popular as in Northern Eurasia but to the west of the Rockies it plays a lesser role in mythology. In the American subarctic from Alaska to Labrador Ursa Major, though well known, is not related to the Cosmic Hunt and is not interpreted as seven persons. The Sami version in Northern Europe is the only one that unites all bright stellar objects like Ursa Major, the Pleiades, Orion and occasionally some other stars and planets in context of the Cosmic Hunt tale (Billson 1918: 180; Charnoluski 1962: 80-81; Eelsalu 1993: 611-612; Kharuzin 1890: 148-149; Lundmark 1982: 93-100).

In Turkic-Mongolian traditions Ursa Major is never associated with the Cosmic Hunt because here, as it was told already, the seven stars have another interpretation, they are strong men or robbers. In North America seven men are typical for the Plains where the Cosmic Hunt is mostly 
absent and its rare cases (Gros Ventre and Wichita) are related to the Belt of Orion and consequently to the South-Western tradition. In some TurkicMongolian stories every man who turns into a particular star of Ursa Major possesses some special skill (one is a runner another is a shooter, and the like). The motif of 'Extraordinary' companions (Thompson's F601) is combined with Seven men as Ursa Major among the Altai, Tuvinians, Buryat (Alar) and Mongols (Benningsen 1912: 55-57; Nassen-Bayer \& Stuart 1992: 329; Ochirova 1991: 193; Potanin 1893: 140-143, 200-203, no. 4, 36; Sadalova 2002: 215-223, no. 22; Skorodumova 2003: 5-13, 18-22, 58-64;) but also among the Wichita of the southern Plains (G. Dorsey 1904: 69-74, no. 9). Among the Blackfoot, Gros Ventre, Crow, Cheyenne and Sarsi seven brothers are transformed into Ursa Major like their numerous Asian counterparts though not differentiated according to their skills (Kroeber 1907: 105108, no. 27; Lowie 1918: 205-210; Michelson 1911: 244-246, no. 2; Simms 1904: 181-182). In some Asian (Tuvinian and Mongolian) and American (Blackfoot, Gros Ventre, Cheyenne) tales seven men turn into the Pleiades (Curtis 1976: 143-144; Kroeber 1907: 105-108, no. 27; Potanin 1893: 322; Samdan 1994: 293-301, no. 7; Wissler \& Duvall 1908: 68-70, no. 7) while the Kiowa tale does not specify whether seven brothers turn into Ursa Major or into the Pleiades (Parsons 1929: 9-11, no. 3). It is difficult to say if this shift, from Ursa Major to the Pleiades, emerged only once in Eurasia and was reproduced in America or the American cases are independent.

\section{URSA MAJOR AS AN ANIMAL AND AS THREE HUNTERS AND ANIMAL}

In Eurasia, to the north of the Altai-Sayan region across the Circum-Yenisei area, not only among the Khanty, northern and (with lesser details) southern Selkup, Ket and Western Evenki (Alekseenko 1976: 84-85; 2001: 6465, no. 10; Lukina 1990: 69, no. 9; Osharov 1936: 22; Pezhemski 1936: 273 275, no. 2; Potanin 1983: 778; Prokofieva 1961: 64-65; Tuchkova 2002: 9596; Vasilevich 1959: 162-163) but also among the Orochon Evenki of the Far East (Mazin 1984: 9-10) four stars of the Dipper are interpreted as an animal (elk) and three stars of the handle as three hunters of different nations competing to be the first to hit the target game. Cosmic Hunt myths of the Khakas are of the Turkic-Mongolian type and related to the Belt of Orion but one tale is similar to the Circum-Yenissei pattern, though according to it four stars of the Dipper are not an elk but two dogs and two deer (Radlov 1907: 273-274, no. 181). The different psychological characteristics of the three hunters are highly specific details that evidence in 
favour of historic links between the Circum-Yenissei and Orochon versions. These links can be further followed to the North American Salishan (in particular Thompson) traditions of the Northern Plateau (Teit 1900: 341342 ) and to Iroquois and Algonkian traditions of the Northeast (Fox, Seneca and probably other Five Nations, Micmac, Lenape) as well as to the Cherokee who lived to the South of other Iroquois (Berezkin 2006a). In most of these versions, both American and Siberian, Alkor is either a cooking pot or a dog and three hunters possess different characteristics though in the American Northeast they are not men of different nations but birds of different species. In the Plateau area there are, in addition, several versions which are similar to the Thompson one though do not provide psychological characteristics for separate hunters (Lillooet, Thompson, Shuswap, Snohomish, Puyallup-Nisqualli, Coere-d'Alene, Wasco).

"Three hunters and animal"version of the Cosmic Hunt, with its unique ideas concerning Alkor, can be interpreted as a very specific conception having emerged in Eastern Siberia and brought to America, possibly relatively late considering its areal distribution in the Plateau area to the north of the region where „Orion's Belt as three animals pierced with a hunter's arrow" was widespread.

„Three hunters and animal" looks like a combination of two independent ideas: all seven stars of Ursa Major together are an animal (bear or elk) and every one of main stars of Ursa Major is a particular person. However, it is not at all certain that ancestors of those North American Indians, who settled across the middle and southern parts of the continent, were probably familiar with the conception of Ursa Major as a bear, elk, mountain goat, etc. in their Siberian homeland. We had to think so because in North America the interpretation of Ursa Major, as an animal, is present mostly in the northernmost areas of the continent among the Eskimo and some groups of Northern Athabaskans and Algonkians, and only among the Eskimo is it not associated with a fisher, woodchuck and the like but with a big game animal (a reindeer) (Fortescue a.o. 1994: 351; MacDonald 1998: 79-81). Among all these northern groups Ursa Major is never related to the Cosmic Hunt. Another cluster of „bear" names for Ursa Major exists among the Pueblo Indians (Eastern Keres, Towa and possibly Zuni) (Gibbon 1964: 244; Reagan 1927: 726-727) but the information is mininal and not related to the Cosmic Hunt and the Navajo case, reconstructed by Gibbon, is even more doubtful.

Two possibilities are plausible - the interpretation of Ursa Major as a bear or elk can be late and did not exist at all at the time of the peopling of the New World by the ancestors of the American Indians. In this case „Three hunters and an animal" is rather a source for this concept than the result 
of its merging with the concept of "Seven men“. Other possibility is that interpretation of Ursa Major, as a bear or elk in Pleistocene times, was widespread mostly or only in Western Eurasia, only reaching Northeast Asia shortly before 5000-6000 B.P. so that the ancestors of the Escoaleuts could borrow it and bring to America or that either corresponding traditions of Northeast Asia and American arctic are not historically related at all to the Western Eurasian traditions.

In favour of the great age of the interpretation of Ursa Major as a big ungulate animal, or a bear, is the wide spread use of these names across Europe and Western Asia. The bear is typical for more southern areas (Ancient Greek, Hebrews, Phoenicians, Arabs, Ancient Romans, Italians, Spanish, Portuguese, French, Megrelians) (Allen 1899: 421-423; Mladenova 2006: 79; Monroe \& Williamson 1987: 15) while the elk is absolutely predominant in northern and central Russia, recorded in Belorussia, among Mordva and Mari of Middle Volga and among some groups of Sami (Erdödi 1968: 117; Pentikäinen 1997: 118; Potanin 1883: 711; Rut 1987: 17; San'ko 2004b: 453; Shkalina 2003: 81; Sviatski 1961: 117-118). For the Romance traditions of Europe it is practically impossible to discriminate folk beliefs that have been passed orally from the data derived from antique sources and returned back to folklore so we are not sure at all that Iberians and Celts shared the concept of Ursa Major, as a bear, with medieval Spanish and French. C. Volpati (1933a: 453) was of opinion that the concept of Ursa Major as a bear was never deeply adopted by the Romance folk traditions. Ancient Greek, Latin and Semitic data on identification of Ursa Major with a bear are, however, certain. North African data, scarce as they are, also support the hypothesis of widespread (and by extension, early) identification of Ursa Major with a big animal though not with a bear. For the Tuareg, Ursa Major and Ursa Minor are two camels, mother and calf, who walk around the pole, i.e. Polaris (Bernus \& ag-Sidiyene 1989: 144). Among the Teda (Saharan people of northern Chad) Ursa Major is named 'Wild Ass' and its seven stars are interpreted as seven wild asses that walk around a well, i.e. Polaris (Kronenberg 1958: 106). The Lezgin of the Eastern Caucasus seem to be unique in identifying Ursa Major and Ursa Minor with a big and smaller dogs, any explanations of these names being lost (Rizvanov \& Rizvanov 1990: 41).

The Northern European zone of the spread of identification of Ursa Major with an elk continues to the east of the Urals. Forest Nenets, Mansi, Hanty, South-Western (Lower Angara, Sym) and Southern (trans-Baikal area, Far East) Evenki associate all the seven stars of the constellation and not only four stars of the Dipper with an elk pursued by hunter or hunters (Anisimov 1959: 15; Lukina 1990: 67-69, 297, no. 8, 110; Mazin 1984: 9-10; 
Munkácsi 1908: 251-253; 1995: 112-116; Okladnikov 1950: 299; Osharov 1936: 13; Potanin 1893: 385; Rombandeeva 2005: 305-307, no. 43; Semenov 1994: 115; Vasilevich 1959: 163). Tundra Nenets, Enets, Nganasan and Yakut seem to be unfamiliar with the concept of Ursa Major as an animal and among the latter the Cosmic Hunt myth was related to Orion (Ergis 1974: 135; Seroshevski 1896: 660) while Ursa Major was a larder on posts (Anikin 1994: 86-87; Potanin 1883: 710, 942) and this finds parallels among people of Lower Amur (Anikin 1990: 19; Avrorin \& Kozminski 1949: 328; Bereznitski 2003: 80; Kreinovich 1929: 81; Lopatin 1922: 331; Podmaskin 1991: 12; Sem 1990: 118-120; Smoliak 1976: 136).

After a major gap in Eastern Siberia, Ursa Major, as an elk, appears again in the sky lore of the Kamchadal, Koryak and probably Yukaghir. We lack direct data regarding the latter but such a tale was recorded among Russian-speaking mixed bloods in Markovo and (elsewhere?) in Anadyr region (Bogoras 1939: 29; Diachkov 1992: 232; Potanin 1883: 942; Sviatski 1961: 119). The probable Yukaghir case is the only one in the Asian Northeast in which the sky elk was thought to be pursued by hunters. For the Chukchi, Ursa Major was six hunters and a fox gnawing reindeer antlers, the latter identified with Alkor (Bogoras 1902: 593; 1939: 25). We find similar identification among the Iglulik Eskimo of Canadian Arctic (MacDonald 1998: 81). The fact that Paleoasiatic cosmonymy was more concentrated on interpretation of Orion and the Pleiades than Ursa Major also brings it closer to the Eskimo patterns. The Yukaghir cosmonymy could be related to the Ob-Ugrian and southern Evenki though not enough is known about this.

Paleoasiatic-Eskimo and European-Siberian versions of Ursa Major, as a big animal, share no specific details yet unlike them, interpretations of Ursa Major, as seven men all across Eurasia and North America, do possess such details.

\section{AFRICAN VS. EURASIAN ORIGINS OF THE COSMIC HUNT}

Cosmic Hunt and the seven stars of Ursa Major, as a large animal, are linked in the context of one and the same tale only in Siberia. Cosmic Hunt is known across a much wider territory than the concept of Ursa Major as a big animal and it is an argument in favour of its greater age. Independent emergence of Cosmic hunt on different continents is unlikely because of two reasons, the first one being that African, Eurasian and North American versions share peculiar details. The second and, perhaps, more important fact is the absence of Cosmic Hunt across Australia, Oceania and the 
Indo-Pacific borderlands of Asia, a fact evidencing against easy spontaneous emergence of such ideas among any people who practiced hunting. In one Maori and two or three Australian tales certain constellations are interpreted as hunters who pursue birds (Bonwick 1870: 189; Reed 1999: 210-211; Waterman 1987: 99, no. 3860.1) but the stories themselves are not about the hunting as their topics are different. Unlike them, the South American stories, (Siona and Secoya, Kaliña, Napo, Kamaiura, Mataco, Chorote, Toba, Mocovi, possibly Tehuelche, more distant parallels among the Locono and possibly Akawayo), have the pursuit of the game as their principal theme and in this respect do not differ from their northern counterparts (Magaña 1983: 32, 35; Mercier 1979: 49-51; Münzel 1973: 187-190; Rivera de Bianchi 1973: 704; Roth 1915: 260, 265-266, no. 205, 211; Vickers 1989: 161-167; Wavrin 1979: 65-66; Wilbert \& Simoneau 1982a: 37, no. 1; 1982b: $27-28,40-41$, no. 2 , 7; 1985 : 254 , no. 135 ; 1988 : $17-33$, no. 5-12; 1989: 24-30, 33, 37-41, no. 13-17, 19-23). In South America participants of the Cosmic Hunt are associated with Orion, the Pleiades or Southern Cross. Among the Desana (Eastern Tucanoan group in Columbia) Cosmic Hunt is not described but Orion is interpreted as a hunter, gatherer or fisherman who carries game, fruits or fish across the sky (Reichel-Dolmatoff 1982: 169-170). Ursa Major, though known, is never associated with hunting.

The Cosmic Hunt is the only widespread star myth in sub-Saharan Africa and it is there always related to Orion. In typical versions (Chokwe, Congo, Songye, Luba-Kasai, Gogo, Yoruba, Bambara) one star is a game animal, another a dog and the third one a hunter (Nilsson 1920: 119-120; Pâques 1964: 170; Studstill 1984: 127-131; Thomas 1919: 180; Vieira 2009: 559; Weeks 1909: 477). In other cases identification of particular stars can be different but the basic principle of one star as one person or animal remains. Among the Sakata and the Tswana all the three stars are dogs, in the Khoikhoi (Hottentot) version all the three stars are animals (zebras) and the Sword of Orion is the hunter and in the version of the Karanga of Southern Zimbabwe three stars are wild pigs and the Sword is a dog or dogs (Colldén 1971: 162; Koekemoer 2007: 75; Nilsson 1920: 120; Sicard 1966: 42-43). In South Africa, data on star lore are somewhat more abundant than in other areas. Three stars of the Belt are usually identified here with three animals even in absence of the Cosmic Hunt myth itself, e.g. three rhinos among the Venda and three zebras among the Kung Bushmen (Gottschling 1905: 382; http://www.psychohistorian.org/astronomy/ethnoastronomy/ african_star_lore.php).

Versions, according to which participants of the story are identified, not only with separate stars of Orion but also with entire groups of stars, are registered only in West Africa. In another version of the Bambara myth, 
Sirius is a dog, Orion is a hunter, the Pleiades and the Hyades are antelopes of two different species (Pâques 1964: 166). The Temne of Sierra Leone say that the hunter is Orion and the Pleiades are chickens which he is going to shoot (Hirschberg 1929: 326-327; Nilsson 1920: 120; Sicard 1966: 42-43). Interpretation of the Pleiades as chickens is certainly late (Berezkin 2009 c) as possibly is the very idea to combine, into a coherent picture, star objects distant from each other.

Both Tropical African (hunter, dog, game) and Khoikoi (three animals and a hunter) patterns have counterparts in Asia, where something like the first variant is found in Dagestan among the Rutul according to whom three stars of the Belt are a dog who pursues a wolf, a wolf who pursues a goat, and the goat itself while the Orion's Belt is the second goat (Bulatova 2003: 222). The Khoikhoi variant finds analogies in Turkic-Mongolian North American South-Western myth according to which three stars of the Belt of Orion are three deer pierced with an arrow.

If African and Eurasian cases are historically related, arguments in favour of localization of prototypical ideas in Asia seem to be more persuasive though not decisive. The existence of the South-Western North American versions of the Cosmic Hunt based on interpretation of the three stars of the Orion's Belt and similar to minor details to the Southern Siberian Central Asian versions evidences in favour of the presence of the latter in Eurasia since at least Terminal Pleistocene. A dog that is persistently included into the African stories was domesticated in Eurasia and certainly was not known in Africa before Early Holocene times. Therefore the African Cosmic hunt tale could be of the same age and source as that version of Muddled message tale that relates the origin of death to the behaviour of a $\mathrm{dog}$, sheep, or goat while in original African versions mentioned were hare, lizard and chameleon (Berezkin 2009a). If African versions are really derived from the Asian ones, this, however, hardly could have happened during the last three or four millennia because the Cosmic Hunt stories are absent both in Ancient Egyptian and Near Eastern mythologies and in recent Near Eastern and North African traditions. For the latter, Ursa Major is the important stellar object while the Belt of Orion is not and is sometimes completely ignored.

The Arabian interpretation of Ursa Major finds precise parallels in North America. From pre-Islamic times up to late $20^{\text {th }}$ century the Arabs of the Near East identified the Dipper with a funeral bier and the handle with three women who follow the bier and are eager to avenge the death of the killed man (Allen 1899: 432-433; Bailey 1974: 583). In North America, the „bier" interpretation is registered in the Plains among Arikara, Santee (and possibly other Sioux-Dakota groups), Omaha, Pawnee, Osage, Quapaw 
with distant parallels in the Southeast among the Caddo and Natchez (Dorsey 1895: 130; Lankford 2007: 152-159). In both Siouan and Arabian versions Alcor is a baby carried by a woman. An interpretation, that is definitely related to the Arabian one, is registered among the Shugnan of Pamir (Lashkarbekov 2008). In this version all the participants are men (four sons of the deceased carry his funeral bier and three others follow it, and Alcor is a sheep to be sacrificed). It is not excluded that other Asian versions of these myths will be found.

\section{URSA MAJOR AS SEVEN MEN}

The shift of attention from Orion to Ursa Major in Northern and Western Eurasia could be related to the development of the ever more detailed picture of the night sky in general and discovery of Alkor in particular. In Eurasia, from Western Europe to Southern Siberia, and across North American Plains, Alkor is interpreted as a young boy or girl, a younger sibling, usually abducted or rescued, or alternatively as a dog. Alkor, as a girl or youth is recorded among the Ancient Romans and Greeks, Italians (at least in Sicily), English, French, Germans, Hungarians, Rumanians, Bulgarians, Macedonians, Kabarda, Circassians, Ossetians, Turkish, Kazakh, Kirgiz, Altai, Teleut, Khakas, Kalmyk (probably), Shugnan of Pamir (probably, with an alternative interpretation as a sheep), Mongol, Buryat, trans-Baikal Evenki (possibly), Blackfoot, Crow, Sioux (probably the Santee), Quapaw, Cheyenne, Wichita (Abishev 1949: 12-13; Allen 1899: 445-446; Andree 1878: 105; Benningsen 1912: 55-57; Brudny \& Eshmambetov 1989: 373-374; Butanayev 1975: 234-235; Chibirov 1962: 87; Diakonova 1976: 286; G. Dorsey 1904: 74-80, no. 10; J. Dorsey 1895: 130; Erdödi 1968: 113; Erdoes \& Ortiz 1984: 205-209; Gamzatov \& Dalgat 1991: 305; Garf \& Kuchiyak 1978: 196204; Gibbon 1964: 240; Holmberg 1927: 428; Lankford 2007: 152; Lashkarbekov 2008; Lowie 1918: 126; Mándoki 1965: 127; Miller 1882: 300; Mladenova 2006: 78-81; Nikonov 1980: 296; Ochirova 1991: 193; Potanin 1883: 200-203, 714, 784; 1899: 574; 1919: 84; Sadalova 2002: 215-223, no. 22; Spence 1985: 182-184; Tsenev 2004: 76, 81-83; Volpati 1933a: 458-459; Voskoboinikov 1958: 165, no. 67). Alkor was interpreted as a dog by the Basque, French, Rumanians, Bulgarians, Ukrainians, Mari, Udeghe, Oroch, Coastal Salish (Snohomish, Puyallup-Nisqualli, Twana), Lillooet, Thompson, Wasco, Sarsi, Crow, Pawnee, Fox, Mohawk and Lenape (Berezkitski 2003: 80; Clark 1953: 148-149, 155; Elmendorf 1960: 537; Gibbon 1972: 243; Hines 1996: 32-35, no. 5; Jones 1907: 71-75, no. 4; Kabakova 1998: 36-38, no. 23; Krappe 1930: 264; Lowie 1918: 205-211; McCleary 1997: 69-72; 7173; Mladenova 2006: 78, 239; Potanin 1883: 713; 1899: 414; Rustige 1988: 


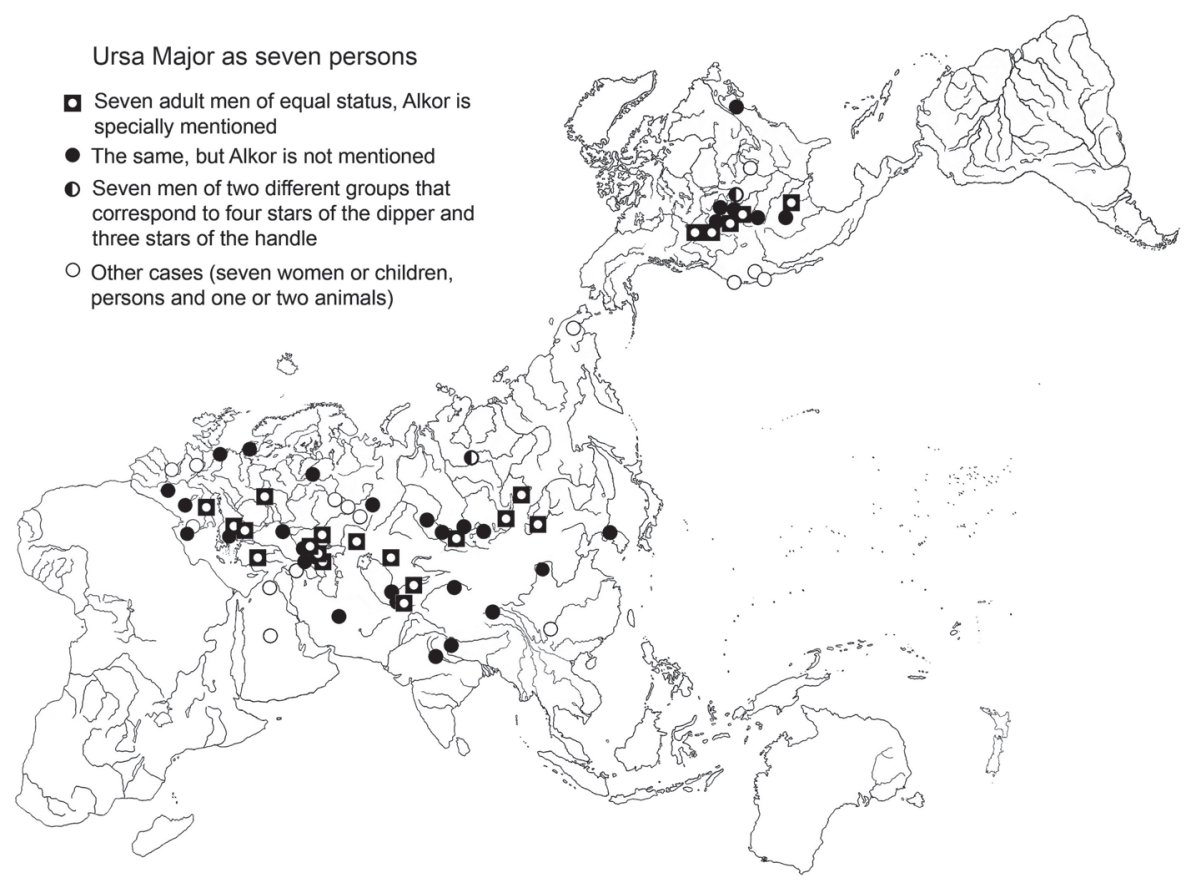

Figure 1. Ursa Major as seven persons.

32-34; Simms 1904: 181-182; Smith 1940: 134; Teit 1900: 341-342; Volpati 1933a: 459). Bulgarians, Serbians, Slovenians, Rumanians, Estonians and Livonians described it also as a wolf (Jankovich 1951: 144; Loorits 2000: 153; Matičetov 1972: 66, 71-73; Mladenova 2006: 237-239; Popov 2003: 271; Prüller 1961: 294). In Ancient Mesopotamia Alkor was identified as a fox but at the same time it was „a star that stands on the pole of a wagon“ (Kurtik 2007: 239-240) that is very near to the interpretation of Alkor as a „small rider“ in Ancient Rome and in later Western and Central European traditions.

Both in Eurasian and in North American tales about transformation of a group of brothers into Ursa Major the main actors are six or seven men and one girl. In Eurasia this girl is usually a marriage partner but in American versions she is a sister of the brothers. All versions from the Plains, as well as the Penobskot tale from New England, are similar and probably developed from the same original source. A Californian variant recorded among the Chumash is hardly related to the others as according to it, Ursa 


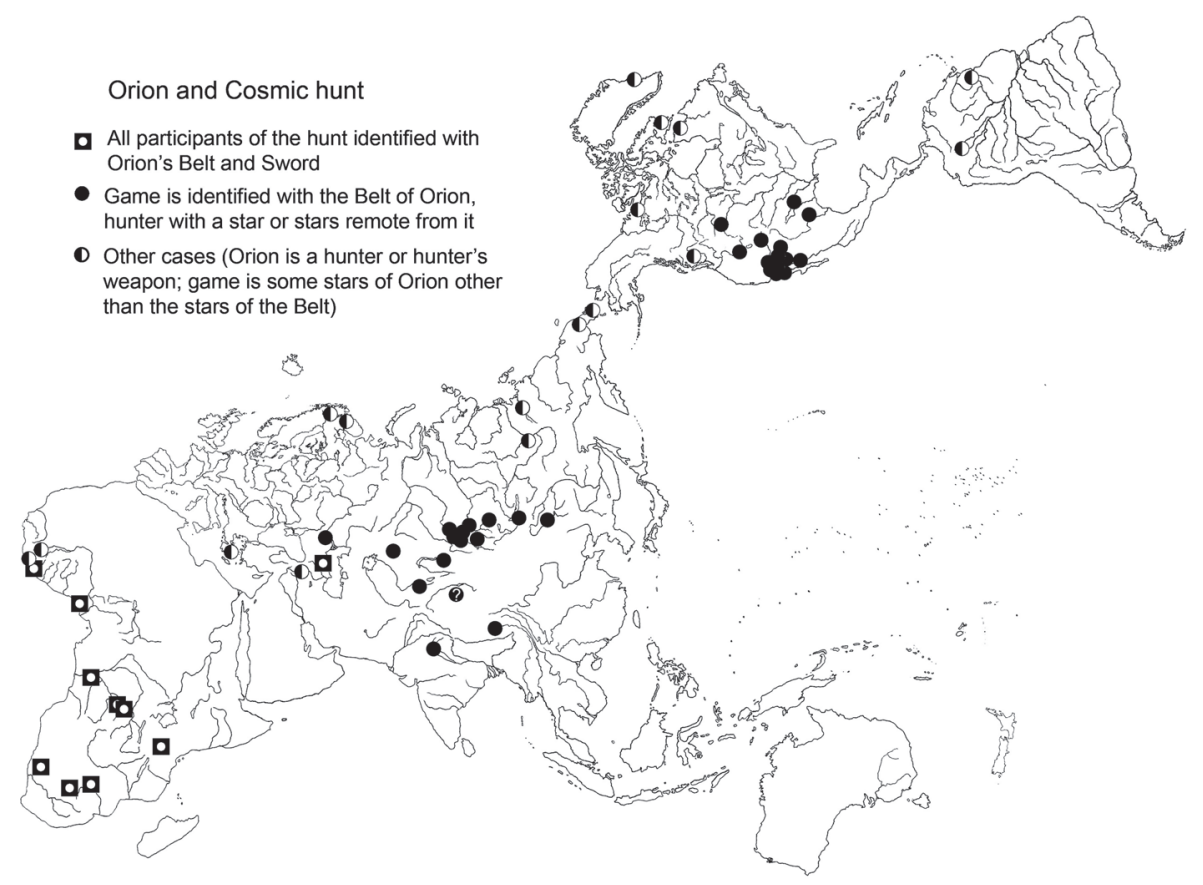

Figure 2. Orion and Cosmic hunt.

Major is seven boys and not adult men (Blackburn 1975: 245-248, no. 57). In similar tales describing conflict of children with their mothers, the children usually turn into the Pleiades, so the shift to Ursa Major looks here like a chance local deviation. The Monache version lacks any details but was probably similar to the Chumash one (Driver 1937: 87, no. 1306).

In Europe besides the Balkans, interpretation of Ursa Major as seven men is relatively well known in the western Mediterranean (continental Italian, Sardinian, Catalan on Mallorca, Maltese) (Amades 1930: 295; Volpati 1933a: 461), rare in more northern areas of Europe (Flanders, Ukraine, Novgorod province in Russian (Gundel 1922: 113; Joanidi 1978: 41; Potanin 1883: 714)) and probably completely absent in the European North. The particular identification of these men with a group of robbers is known not only in the Balkans but also among the Italians (Volpati 1933a: 461). The Osmanian influence ("Seven brothers", Mladenova 2006: 81) is not here excluded but still this case can be also taken as an evidence of the early westward spread of this motif. 
In Asia the easternmost case of interpretation of Ursa Major as seven men is among the Koreans (Choi 1979: 167, no. 390). The interpretation of Ursa Major known to the early inhabitants of the Pacific Asia whose descendants reached America could be "canoe“. This meaning is recorded on Bali, Okinawa, Marshall Islands, Aleut Islands, among the Muskogee (Alabama and Seminole), West India and Guiana Caribs (Bergsland 1994: 218; Erdland 1910: 21; Greenlee 1945: 138-140; Kitao 2002: 25; Magaña \& Jara 1982: 115; Monroe \& Williamson 1987: 111; Robiou-Lamarche 1986: 484). Episodic presence of "canoe" also in Europe and the Mediterranean (Mladenova 2006: 85-86; Porsanger 2005: 26-27) makes it difficult to prove the historic links between the Pacific traditions though Okinawa and Marshall Islands versions are almost certainly related. According to both only five major stars of the constellation without $\alpha$ and $\beta$ mark the outline of the boat.

The Old and the New World areas of Ursa Major as seven men are separated with vast territories of the Northeast Asia and Northwest North America where this concept is practically absent. The northernmost Siberian case is recorded among the western Evenki of Lower Tunguska. Three brothers had a lot of reindeer, four brothers from the sky stole the reindeer and three brothers came to the sky to get them back. The reindeer turned into multitude of stars, the sky brothers into four stars of the Dipper, three brothers into three stars of its handle (Yermakov 1988: 35-36). Unlike Southern Siberian versions, the Evenki one does not mention Alkor while the stars of the Dipper and handle are split into two sets, four and three, that is characteristic for some versions of Cosmic Hunt (three hunters and four animals) but not for the typical Eurasian and American Seven men tales.

The area of the spread of the 'Seven' men concept in Eurasia is mostly inside territories that during the last glacial period were not covered with ice and the arctic deserts. Such a geographical spread fits well the terminus ante quem dating of 'Seven' men in Southern Siberia - Central Asia based on the existence of precise parallels across the North American Plains.

Because of the wide spread and probably great age of both the Cosmic Hunt motif and of interpretation of Ursa Major as seven men, the very emergence of the concept of constellations selected from the undifferentiated picture of the night sky in the Old World outside of Indo-Pacific regions could be related just to these myths. 


\section{URSA MAJOR AS A CART COMBINED WITH THE 'SEVEN' MEN CONCEPT}

In most of the modern (Spanish, Catalan, Portuguese, French, Irish, German, Danish, Swedish, Icelandic, Estonian, Latvian, Lithuanian, Livonian, Slovenian, Serbian, Bulgarian, Croatian, Macedonian, Rumanian, Hungarian, Albanian, Polish, Czech, Slovakian, Ukranian, southern and central Russian in Kostroma, Nizhni Novgorod, Riazan, Kursk, Orel, Tula, Voronezh provinces, Belorussian, Gagauz) and ancient (Latin, Greek, AngloSaxon, Goths) European traditions, Ursa Major is a carriage, a cart (Allen 1899: 420-428; Andree 1978: 104; Amadeus 1930: 225; Chubinski 1872: 14; Kabakova 1998: 34; Kolchin 1899: 9; Krappe 1938: 145, 264-265; Kuperjanov 2003: 133-135; László 1975: 391; Loorits 1926: 81; 2000: 153; Matičetov 1972: 53-54; Mickiewicz 1955: 434; Mladenova 2006: 72-77; Moshkov 1901: 55; Niebrzegowska 1999: 147-148; Popov 2003: 271; Potanin 1899: 414; Prüller 1961: 294; Rut 1987: 17; Sviatski 1961: 113; Tiurina 1972: 53; Tsenev 2004: 83; Vaiškūnas 1999: 167; 2004: 173; Volpati 1933b : 38; Werner 1912: 195). It was the same in ancient Near Eastern traditions of Sumerians, Babylonians and Hittite (Ivanov 1977: 123-124, 284; Kurtik 2007: 239-249). If the origin of this name was in the Near East or in Europe, its spread definitely could not precede the invention and spread of the wheeled vehicles themselves. Because Ursa Major as a cart is known practically to all Indo-European traditions in Europe and not known to most of other traditions besides those engaged in intensive cultural interaction with the IndoEuropeans (Hungarians, Estonians, Gagauz), we can suggest that it was known also to those Indo-European groups who in III-II millennia B.C. migrated far to the east. In favour of such a suggestion is a unique Mongolian case of Ursa Major as Tergel od ("Cart-star") recorded by Academic Mongolian-Russian dictionary (Kozmin 2008: 17). R. Allen (1899: 435) cites a similar Ancient Chinese name Ti Tche, „the Emperor's Chariot" adding that "this was doubtless a latter designation from Jesuit teaching“. However, this interpretation of Ursa Major is found already in Sima Qian's „Shi Ji“(109-91 B.C.) (Syma Tsyan 1986: 115-116). Such a meaning both in Mongolia and in China can ultimately go back to some Bronze Age IndoEuropeans of Central Asia. However, to the south of the steppe zone in Central Asia, Iran and India the Indo-European "cart" either never was known or at least did not survive. In these regions (Uzbek, Tajik, Persian, Ishkashim, Vakhan, Hindu) the only interpretation of Ursa Major is „seven men" (Andreev \& Polovtsov 1911: 35; Nikonov 1980: 295; R. Rakhimov, personal communication, 20.10.2009; I. Steblin-Kamenski, personal com- 
Ursa major is identified with a carriage, a cart

- Data before A.D. 500

- Data after A.D. 500

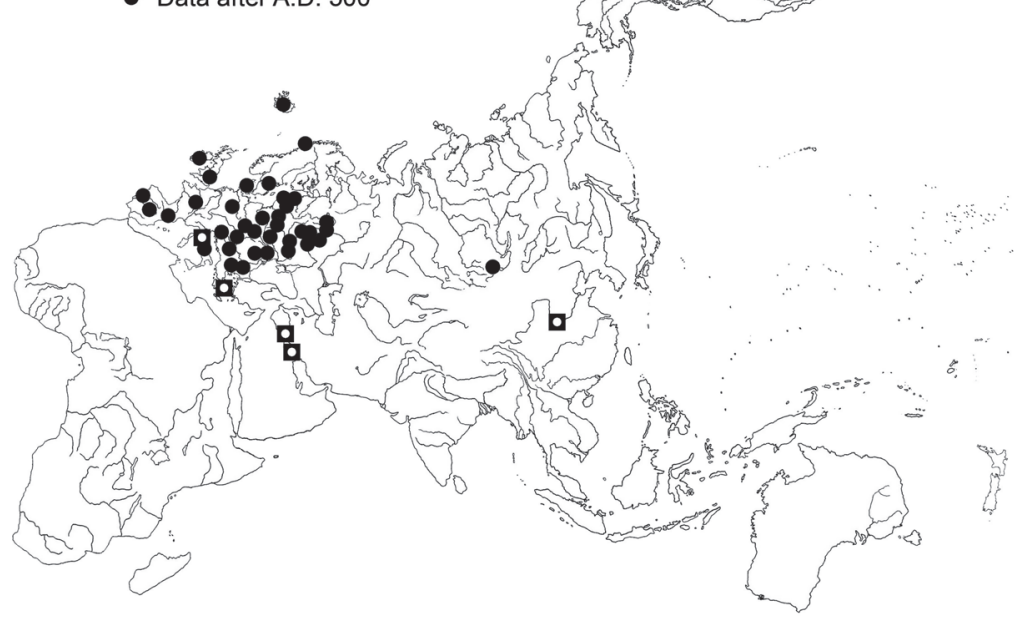

Figure 3. Ursa Major as a cart.

munication 11.08.2006; Vassilkov \& Neveleva 1987: 617). The same interpretation is typical for the Caucasus where it is recorded among the Adyg, Kabarda, Abkhaz, Ossetians, Ingush, Chechen, probably Georgians and Armenians (Aliroev 1976: 224-225; Chibirov 2008: 87; Dalgat 1972: 337; Khvartskia 1994: 60; Kokov 1980: 171; Meretukov 1980: 173; Miller 1882: 300; Potanin 1883: 714).

The Seven women are known across more or less the same latitudinal belt of Eurasia as Seven men among the Armenians, possibly Greeks of Rhodes and Cyprus, Nuristani, Volga Tatars, Bashkir, Chuvash, Khakas, Bedouins of Syria and Arabia and western Miao in China (Barag 1987: 34, no. 6; Davletshin 1979: 48; Ganalanian 1979: 123, no. 326; Graham 1954: 250-252; Henninger 1954: 91-92; Litvinski 2004: 123; Mladenova 2006: 86; Nadrshina 1985: 11, no. 4; Sirotkin \& Ivanov 1970: 129; Rassadin 1996: 7 8, no. 1; Vorobiev \& Khisamutdinov 1967: 315) as well as in North America among the Winnebago, Yuki and Kiowa (Foster 1944: 233; Gibbon 1964: 
237; Smith 1997: 28-30). These cases are rare and look like chance deviations of the main "male“ version, especially in America. For example, in the Winnebago tale seven warriors turn into Ursa Minor, seven virgins into Ursa Major and an evil shaman who pursued them in Polaris. According to more common variants from the Plains, men and a girl who run away from the pursuer turn into Ursa Major. Because in the Winnebago example girls are seven, not one, the Ursa Minor seems to be included in the tale. Half a century ago W. Gibbon (1964) discussed relevant North American Indian myths in detail.

Combination of "cart" with „men“ produced complex tales in which different persons and animals participate. One version known in the Balkans and Eastern Baltic describes Ursa Major as a cart, a driver, an ox and a wolf or bear who swallowed the second ox and was put in its place by the driver (Kuperjanov 2010). In another version recorded among the Basque and with some variations in the south-west of France and in Sicily no cart is mentioned but the oxen remain (Kabakova 1998: 36-38, no. 23; Krappe 1930: 264; Volpati 1933a: 458-459). When two thieves stole two oxen, the peasant sent first his servant, then a house maiden and then a dog to pursue them and all the participants reached the sky. The four stars of the Dipper are oxen and thieves, the three main stars of the handle are servant, maiden and peasant and Alkor is a dog.

The image of Ursa Major as a cart acquired additional details already in antiquity. In particular, the interpretation of two stars as oxen that pull the cart being so typical for late European versions being known already in the Roman Empire (Hyg. Astr. II.2). However, complex interpretations, related to constellations as well as to lunar spots, are not recorded in early Greek sources and possibly developed since the Hellenic times. Frequency of chance modifications introduced into tales depends on the number of acts of their retelling. Therefore general proliferation of the folklore is an expected phenomenon in complex multi-ethnic societies with high demographic density. The emergence of such societies in Europe only took place in late Antiquity.

In Northern Europe no predominant way of interpretation of Ursa Major besides „cart“ is recorded. „Dipper“ could be widely known but this name is historically unspecific and episodically registered in different traditions up to Olchi of Lower Amur (Smoliak 1991: 21) and Coastal Salish (Smith 1940: 134). Neither the pursuit of the elk Hiisi in Finnish-Karelian tales nor Finnish Otava (probably: fish-trap) for Ursa Major is related to the Cosmic Hunt while in the Sami eschatological myth Ursa Major is a hunters' bow but neither game animal nor hunters with an animal as in Siberia and North America. The westernmost Siberian-type interpretation of Ursa 
Major in context of Cosmic Hunt myth is for the Mari (elk with its young and hunter with his dog) (Potanin 1883: 713). More distant parallel is among the Chuvash (two hunters with three dogs and two horses were frozen to death and turned into Ursa Major) (Ashmarin 1984: 26). W. Gibbon (1972: 239) includes Komi-Zyrian into groups to which chase of the cosmic elk was known but neither myself nor V. Napolskih (pers. comm.) were able to discover a source of this information. A Siberian type Cosmic Hunt myth, perhaps, could be known in the Eastern Baltic area if it was brought there from the east somewhere in Early Holocene together with the Path of Birds for the Milky Way, Girl with water pails seen in the lunar spots and conception of stars as sky openings (Berezkin 2009b). However, regional distribution of these three motifs in Asia and North America demonstrates a weak correlation with distribution of Ursa Major as a game animal or as three hunters and animal in context of the Cosmic Hunt myth. The latter interpretation of Ursa Major in Siberia much better correlates with interpretation of the Milky Way as a snow track which is alternative to the Path of birds.

To sum up, 'Seven' men is widely known across the moderate belt of Eurasia and was probably a predominant interpretation of Ursa Major in Central and Southern Europe before the spread of its interpretation as a wheeled vehicle. Its interpretation as a bear could also have existed already in the pre-agricultural epoch. Information on a possible spread in Europe of the Cosmic Hunt myth with Ursa Major interpreted as a pursued animal (all seven stars or four stars of the dipper) is, however, rare and uncertain. According to the Ancient Greek myth, Arkas attempted to kill a bear not knowing that the animal was his transformed mother Kallisto. No hunting in the sky is described, however, Kallisto and Arkas being simply transformed first into a bear and bear cub and then into Ursa Major and Ursa Minor (Paus. VIII 3, 3). This identification of two circum-polar constellations with a big female animal and her young reminds us of the Tuareg and possibly Lezgin interpretation that were mentioned above.

\section{SKY OF THE FARMERS}

For Orion and the Pleiades early European meanings seem to be mostly lost and replaced with interpretations related to agriculture or other activities that could hardly develop before Neolithic. Interpretations of the three stars of Orion's Belt and six or seven stars of the Pleiades as persons (men, girls, members of a family) could be known, of course, from any time but they are not specific enough to be used in historical reconstructions. 


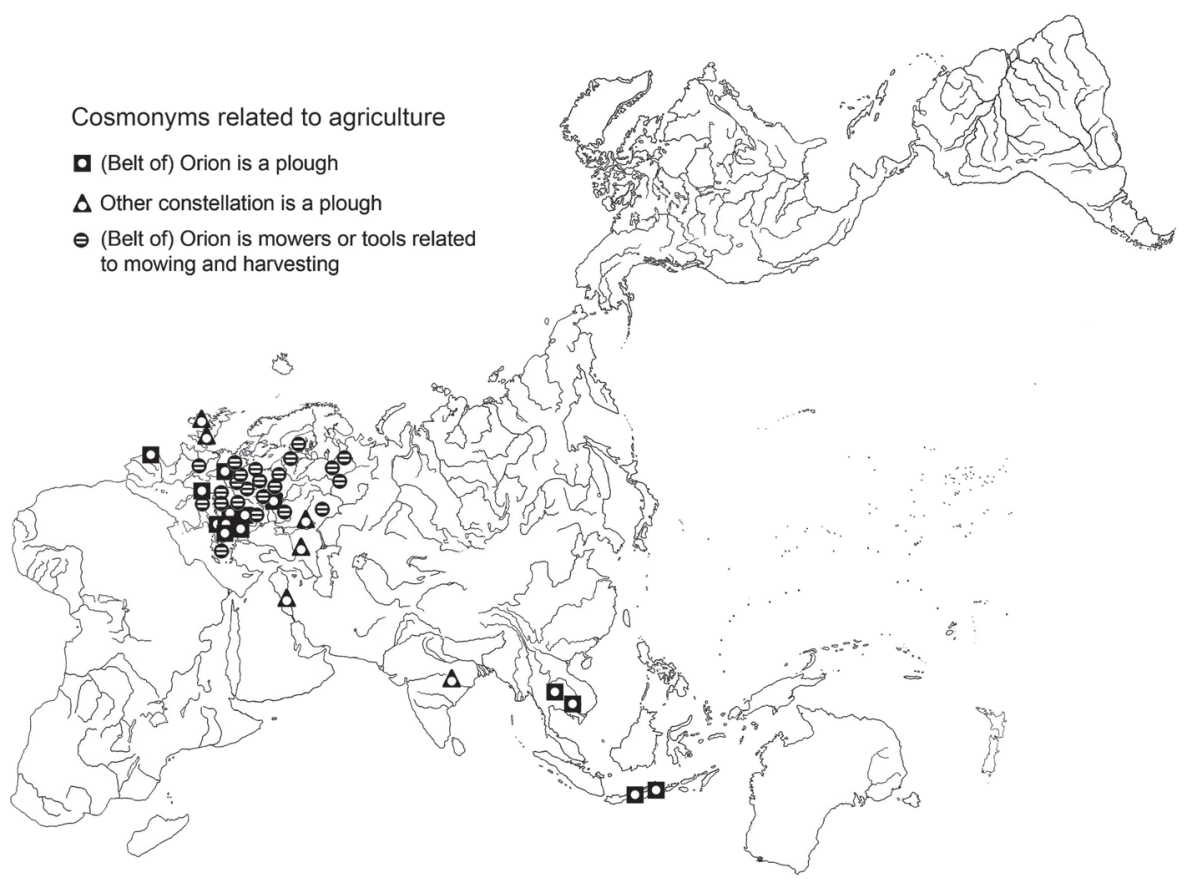

Figure 4. Cosmonyms related to agriculture.

Three meanings all related to agriculture and particularly to harvesting are, in Europe, connected with Orion. The first meaning is tools used for harvesting and processing of hay or cereals such as scythe, sickle, flail and rake. This variant was known to the Italians, French, Estonians, Finns, Slovenians, Kashub, Serbs, Croatians, Slovenians (Belova 2004; Bonser 1928: 346; Kuperjanov 2003: 147, 165; Matičetov 1972: 67; Mladenova 2006: 123, 144; Šmitek 2001: 132-133; Sviatski 1961: 123; Volpati 1932: 162, 170, 172-173). Among Slavic people the meaning „kosy“ (scythes) is sometimes difficult to select from the meaning „koscy“ (mowers). „Mowers“ is the second ,agricultural“ name for Orion widespread in Europe. „Mowers" is registered among the Italians, Germans, Croatians, Slovenians, Bulgarians, Hungarians, Rumanians, Poles, Slovakians, Czecks, Belorussians, Ukranians, Russians and Lithuanians (Andree 1878: 109; Belova 2004; Chubinski 1872: 14; Fedorovich 2009: 17; Gładyszowa 1960: 45; Grimm 1882: 726; Karpenko 1992: 194; Rut 1987: 20; San'ko 2004a: 236; Šmitek 2001: 132-133; Sviatski 1961: 122-123; Vaiškūnas 1999: 167-168; 2004: 176). Russian names related to processing of hay, cereals and flax (rake, flail) are 
The Belt of Orion is

- beam of a scale

d a yoke for pails

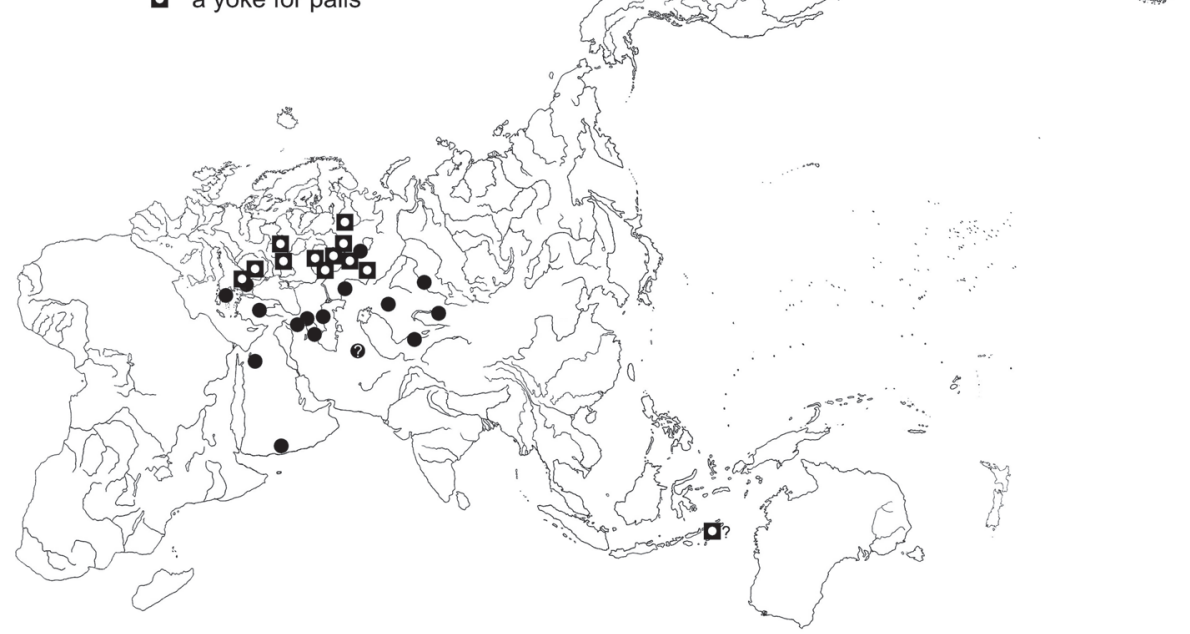

Figure 5. The Belt of Orion as a scale or a yoke.

found only, or at least mostly, in northern provinces and across the zone of later colonization (Ural, Siberia, Saratov province on Volga).

The third „agricultural“ name for Orion in Europe is „plough“. According to many versions, three stars of the Belt are the plough's handle. Orion as a plough is mostly recorded in more southern areas of Europe among the Italians, Galicians, Germans, Bulgarians, Macedonians, Serbians, modern Greek, Albanians, Romanians and Ukrainians (Fedorovich 2009: 17; Mladenova 2006: 120; Stoinov 2006: 263; Sviatski 1961: 123; Znoiko 1989: 49, 212). In Ukraine this concept often correlates with the interpretation of Cassiopeia as a harrow. Among the Russians, the constellation associated with the plough („chipiga“, „chipega,- name for the plough's handle) is registered only in the Don basin in the Russian-Ukranian border zone and the name is applied not to Orion's Belt but to Ursa Major (Rut 1987: 18). The „plough“ for Ursa Major was also known in England, Scotland and Ireland (Allen 1899: 431; Grimm 1883: 727, 730).

Unlike „mowers“, „rake“ and the like that have compact areas of distribution and are not registered by early sources, „plough“ has distant paral- 
lels both in time and in space. Sumerian and Babylonian sources mention the constellation of the Plough though identified not with Orion but with Andromeda and „stars of Northern Triangle“ (Kurtik 2007: 66-70). The Karachai people of Northwest Caucasus interpret Ursa Minor as a ploughshare (Jurtubaev 1991: 136). The Baiga who speak the Central Dravidian language and practice shifting cultivation in Madhya Pradesh identify one group of stars with a plough and another (possibly Belt of Orion) with a stick used both for agricultural work and for washing of clothes (Elwin 1939: 335). But the most near analogies to European concept are among the rice cultivators in Thailand, Cambodia, Java and Bali (Andree 1878: 109; Maaß 1921: 47, 51). These facts could be considered as an accidental coincidence but they fit well a more general tendency of sharing mythological motifs by folk traditions of Europe and of Southeast Asia with no parallels in Ancient European sources (Berezkin 2006b; 2008b). Another spectacular parallel of this kind is a concept of the Pleiades as a hen with its chicken, a group of chickens, etc. It is not found either in Greek or in Near Eastern ancient sources but is widespread in Central and Southern Europe, Tropical Africa (mostly Western) and also in Southeast Asia where the domestic chick was initially domesticated (Berezkin 2010). Mechanism of transmission of Southeast Asian mythology to Europe is far from clear but can be understood in context of exchange of ideas across Eurasia after formation of the „world-system“.

Absence of the Plough in Greek and Roman sources is against the hypothesis of inclusion of such a cosmonym into European sky map thanks to contacts with Mesopotamia. However, ancient sources contain no information on the sky lore of Thracian and more northern areas of Europe where "agricultural“ names of constellations were mostly recorded later by ethnographers. Overall spread of agricultural interpretations of Orion in Europe fits moderately well the spread of the Starčevo-Körös-Criş and its later Neolithic descendents (including LBK) across the Balkans and Central Europe in VI millennium B.C. Penetration of these cosmonyms into Eastern Baltic and present day Russian area could to take place only later, of course.

Constellation names related to harvesting tools and to people who use them are concentrated in central, central-eastern and south-eastern parts of the continent and unknown outside of Europe. The eastern part of the area of their spread is overlapped with the area of interpretation of the Orion's Belt as a yoke which also includes the Middle Volga region. The "yoke" is recorded among the Bulgarians, Romanians, Ukranians (possibly only Eastern), Belorussians, Russians (Orel, Riazan, Arkhangelsk provinces), Chuvash, Mari, Mordva, Volga Tatars, Bashkir (Aktsorin 1991, no. 
37; Davletshin 1979: 48; Mladenova 2006: 132-133, 262; Nikonov 1973: 378; Potanin 1883: 723; Yuhma 1980: 266, 288; Zolotnitski 1874: 23). The case of Bunak of Timor (bamboo pole for carrying water pails) looks like a chance coincidence (Friedberg 1973: 133). To the southeast of „yoke“ mostly in Asia three stars of Orion's Belt are interpreted as a beam of a scale. This variant is found among Arabs of Hadramaut and Bedouins of Jordan, Bulgarians, Greeks, Georgians, Armenians, Azerbaijan, Turks, Udmurt, Kazakh, Kirghiz, Siberian Tatars (Chuloschnikov 1924: 243; Henninger 1954: 112; Kuftin 1916: 128; Mladenova 2006: 139-140; Potanin 1881: 126; 1883: 723; Rodionov, personal communication, 2006). According to R. Allan (1899: 315 ), this concept was known to the Chinese. All information that Allan possessed on the Chinese sky lore had been probably taken by him from Sima Qian's „Shi Ji“. However, in the „Shi Ji“ „Scale“ is associated not with the Belt of Orion but with other stars (Syma Tsyan 1986: 117, 266). The very abundance of Chinese star names related to objects and tools makes doubtful any historic relation between ethnographically known Eurasian and Ancient Chinese cases.

The meaning of both concepts, i.e. Yoke and Scale, is fairly similar and their historical interrelation is especially probable considering the adjacent position of the areas of their spread on the map.

The origin of Scale can be related to the spread of the influence of Islam. Among the Kazakh and Kirghiz this meaning is alternative to the meaning „Three deer" which was related to the Cosmic Hunt myth and certainly much older than Scale. Is Yoke only an offshoot of Scale or has it its own deeper history is still unclear.

It is not excluded that before becoming „wavers“, „rake“, „yoke“ or „scale“, Orion in Europe was interpreted in context of the Cosmic Hunt myth just as it was in Tropical Africa and in Southern Siberia - Central Asia. The Caucasian data partly fill a gap between Africa and Central Asia. Besides the Rutul version mentioned above the Armenian one also exists. When Haik (legendary ancestor of Armenians) died he and his dogs turned into constellations of Orion and Canes Venatici. A relief on a wall of a $4^{\text {th }}$ century A.D. tomb, representing a warrior with two dogs killing a wild boar, possibly illustrates this tale (Stepanian 1971: 13). For the Ancient Greeks Orion was also a hunter.

\section{CONCLUSIONS}

Reconstructing early European ideas about the night sky we should consider interpretations of the sky objects known across all Northern Hemi- 
sphere. Along with idiosyncratic cases, there are several concepts known from Africa to North America. The most widespread Eurasian - North American interpretation of Ursa Major is 'Seven' men with Alkor as a dog or as a younger or weaker person (youth, girl, young woman). This concept must be known across the moderate zone of Eurasia at least since the Terminal Paleolithic and brought from Southern Siberia to the North American Plains. The Cosmic Hunt myth and the interpretation of Belt of Orion in its context probably also emerged somewhere in Central Eurasia and were brought from there to North America and to Africa. African origin of these concepts is not completely excluded. In this case we must suggest, however, that not only a dog as a participant of the hunt was added later (no dogs in Africa before the Holocene) but also that the spread of the motifs in question was from Africa to continental Eurasia and took place well before the peopling of America. This is rather unlikely because no other reliable African - continental Eurasian parallels of the same age have yet been discovered. The available cases of the motifs shared by Eurasian and African traditions can be more easily interpreted as a result of back migrations to Africa from Asia (Berezkin 2009a; 2009b).

In Eurasia those areas where main stars of Ursa Major were identified with seven men and where three stars of Orion were identified with three (rare: one) ungulate animals pierced with an arrow largely overlap but in America they are adjacent. The Belt of Orion, in context of the Cosmic Hunt, is typical for the Southwest while the motif of 'Seven' men is recorded across the Plains and rarely in the Northeast, both motifs being found together only among Wichita and Gros Ventre. This difference in area distribution of these concepts in Asia and in America needs an explanation that I am unable to suggest at the present time.

In the moderate zone of Europe in Mesolithic times Ursa Major was most probably interpreted as seven men but possibly also as an animal, first of all a bear. The mutual relationship of these two concepts is unclear. The circum-Yenisei interpretation of Ursa Major as three hunters and a game animal (an elk) looks like combination of both. If the Cosmic Hunt was known in Mesolithic Europe at all, it was probably related to Orion. For northwest Europe deep reconstructions are hardly possible because the data on folk cosmonymies here are too scarce. The epic and eschatological picture of Cosmic Hunt among the Sami is unique. Because Orion, Cassiopeia and the Pleiades are incorporated into it, parallels are not with more southern European but with more eastern Arctic traditions such as Nganasan, Northern Yakut, Paleoasiatic, Eskimo and especially with Chukchi and Chukotka Yupik (Bogoras 1939: 25-29; Ushakov 2001: 172). 
The interpretation of the Pleiades as a hen with chickens and of Orion as agricultural tools or harvesters, as a yoke and as a scale could not exist before the Neolithic. „Chickens" were probably brought from Southeast Asia after the continental-wide system of communications was well at work and for Plough such a hypothesis also is not excluded. „Mowers“, „flail“, „rake“ etc. look like local inventions possibly as early as the first European cultures with a productive economy though much later origin is also possible. The Yoke and Scale can be as late as from Islamic influence and the topic needs further investigation.

It should be recognized that the data available now are not sufficient for reconstruction of the star-lore of the distant past with desired reliability, and many suggestions are conjectural. The search for additional cosmonymic materials both published or preserved in the archives is necessary.

\section{BIBLIOGRAPHY}

Abishev, Kh. 1949. Elementy astronomii i pogoda v ustnom narodnom tvorchestve kazakhov [Elements of astronomy and weather in Kazakh folklore]. AlmaAta: Izdatel'stvo Akademii nauk Kazakhskoi SSR.

Abrahamsson, Hans 1951. The Origin of Death. Studies in African Mythology. Uppsala: Theological Faculty of the University of Uppsala.

Aktsorin, Vitali A. 1991. Mariiski folklor [Mari Folklore]. Yoshkar-Ola: Mariiskoe knizhnoe izdatel'stvo.

Alekseenko, Yevgenia A. 1976. Predstavlenia ketov o mire [The worldview of the Kets]. - Priroda i Chelovek v Religioznyh Predstavleniyah Narodov Sibiri $i$ Severa. Ed. by I. S. Vdovin. Leningrad: Nauka, s. 67-105.

Alekseenko, Yevgenia A. 2001. Mify, predania, skazki ketov [Myths, Legends, Folktales of the Kets]. Moscow: Vostochnaia Literatura.

Aliroev, I. Yu. 1976. Astronomicheskaya terminologia v vainahskih yazykah [Astronomic terms in Vainakh languages]. - Arkheologo-etnograficheski sbornik.

Vol. 4. Grozny: Checheno-Ingushskoe izdatel'stvo, s. 221-224.

Allen, Richard H. 1899. Star-Names and Their Meanings. New York, Leipzig, etc.: G.E. Stechert.

Amades, Joan 1930. Astronomia i meteorologia popular. - Butlleti de Dialectologia Catalana 18, p. 105-138, 217-313.

Andreev, Mikhail S. \& A. L. Polovtsov 1911. Materialy po etnografii iranskih plemen Srednei Azii. Ishkashim $i$ Vakhan [Materials on Ethnography of Iranian Tribes of Central Asia. Ishkashim and Wakhi]. Saint-Petersburg: Muzei Antropologii i Etnografii.

Anikin, Aleksandr Y. 1990. K tipologii nazvanii Bolshoi Medveditsy v yazykah Sibiri [To typology of Ursa Major names in Siberian languages]. - Izvestia Sibirskogo Otdelenia Akademii Nauk SSSR. Seria istorii, filologii i filosofii. Novosibirsk: Nauka. Iss. 3, s. 18-22. 
Anikin, Aleksandr Y. 1994. K tipologii nekotoryh yakutskih kosmonimov [To typology of some Yakut cosmonyms]. - Yazyk-mif-kultura narodov Sibiri. Ed. L. L. Gabisheva. Yakutsk: Yakutski gos. universitet, s. 86-93.

Anisimov, Arkadi F. 1959. Kosmologicheskie predstavlenia narodov Severa [Cosmological Ideas of the People of the North]. Moscow and Leningrad: Izdatel'stvo Akademii Nauk SSSR.

Ashmarin, Nikolai I. 1984. Vvedenie v kurs chuvashskoi narodnoi slovesnosti [Introduction to the course on Chuvash folk narratives]. - Issledovania po chuvashskomu folkloru. Cheboksary: NII yazyka, literatury, istorii i ekonomiki, s. 3-48.

Avrorin, Valentin A. \& I. I. Kozminski 1949. Predstavlenia orochei o vselennoi, o pereselenii dush i puteshestviah shamanov, izobrazhennye na „karte“ [Oroch ideas about universe, migrations of souls, and travels of shamans represented on a 'map']. - Sbornik Museia Antropologii i Etnografii, Leningrad. Iss. 11 , s. 324-334.

Bailey, Clinton 1974. Bedouin star-lore in Sinai and the Negev. - Bulletin of the School of Oriental and African Studies 37(3), pp. 580-596.

Barag, Lev G. 1987. Bashkirskoe narodnoe tvorchestvo. T. 1. Predaniya i legendy [Bashkir Folklore. Vol. 1. Tales and Legends]. Ufa: Bashkirskoe knizhnoe izdatel'stvo.

Belova, Olga V. 2004. Orion. - Slavianskie drevnosti. Etnolinguisticheski slovar [Slavic Antiquities. Ethnolinguistic Dictionary]. Vol. 3. Moscow: Mezhdunarodnye otnoshenia, s. 560-561.

Benningsen, A. P. 1912. Legendy i skazki Tsentralnoi Azii [Legends and Tales of Central Asia]. Saint-Petersburg: Tipografia A.S. Suvorina.

Berezkin, Yuri 2006a. The cosmic hunt: variants of a Siberian - North-American myth. - Folklore: Electronic Journal of Folklore 31, pp. 79-100.

Berezkin, Yuri 2006b. Do ili posle Zaveta? „Oplevannoe tvorenie“i soputstvuyuschie mifologicheskie motivy v Eurazii [The „spit upon creation“ and attended mythological motifs in Eurasia]. - Kultura Aravii $v$ aziatskom kontekste. Saint-Petersburg: Museum of Anthropology and Ethnography RAS, s. 225249.

Berezkin, Yuri 2008a. Alkor, kotelok i sobaka: mezhkontinentalye kul'turnye paralleli i epohal'nye izmenenia v kartine zvezdnogo neba [Alkor, a cooking pot and a dog: intercontinental cultural parallels and long-term changes in the star map]. - „Kirpichiki“: kul'turnaia antropologia i folkloristika segodnia. Sbornik v chest' 65-letia Sergeia Yurivicha Nekliudova [„The Bricks“: Cultural Anthropology and Folklore Studies Today. Sergei Nekliudov Festschrift]. Moscow: Russian State University of Humanities, s. 11-23.

Berezkin, Yuri 2008b. Afrikanski Vethi Zavet i aziatskoe „narodnoe khristianstvo“? [African Old Testament and Asian „folk Christianity“?] - Mif, Simvol, Ritual. Narody Sibiri. Ed. by S. Yu. Neklyudov. Moscow: Russian State University of Humanities, s. 222-257.

Berezkin, Yuri E. 2009a. Why are People Mortal? World Mythology and the „Outof-Africa“ Scenario. - Ancient Human Migrations. A Multidisciplinary Ap- 
proach. Ed. by Peter N. Peregrine, Ilia Peiros, Marcus Feldman. Salt Lake City: The University of Utah Press, pp. 242-264.

Berezkin, Yuri E. 2009b. Out of Africa and further along the Coast (African South Asian - Australian mythological parallels). - Cosmos (Edinburgh) 23 (1), pp. 3-28.

Bereznitski, Sergei V. 2003. Etnicheskie komponenty verovanii i ritualov korennyh narodov Amuro-sakhalinskogo regiona [Ethnic Components of Beliefs and Rituals of the Native Peoples of the Amur-Sakhalin Region]. Vladivostok: Dal'nauka.

Bergsland, Knut 1994. Aleut Dictionary. Unangaw Tunudgusii. Fairbanks: University of Alaska, Alaska Native Language Center.

Bernus, Edmond \& Ehya ag-Sidiyene 1989. Étoiles et constellations chez les nomads. - Awal: Cahiers d'Qtudes Berberes 5, p. 141-153.

Billson, Charles J. 1918. Some mythical tales of the Lapps. - Folk-Lore 29 (3), pp. 178-192.

Blackburn, Thomas C. 1975. The December's Child. A Book of Chumash Oral Narratives. Berkeley, Los Angeles, London: University of California Press.

Bogoras, Vladimir (Waldemar) 1939. Chukchi. Vol. 2. Religia [Chukchi. Vol. 2. Religion]. Leningrad: Izdatelstvo Glavsevmorputi.

Bogoras, Vladimir (Waldemar) 1902. The folklore of Northeastern Asia, compared with that of Northwestern America. - American Anthropologist 4(4), pp. 577-683.

Bonser, Wilfrid 1928. The mythology of the Kalevala, with notes on bear-worship among the Finns. - Folk-Lore 39(4), pp. 344-358.

Bonwick, James 1870. Origin of the Tasmanians. London: Sampson Low, Son, \& Marston.

Brudny, D. \& K. Eshmambetov 1989. Kirgizskie narodnye skazki [Kirgiz Folktales]. Frunze: Mektep.

Bulatova, Angara Gamidovna 2003. Rutultsy in XIX - nachale XX vv. [The Rutuls in XIX - early XX century]. Moscow: Institut etnologii i antropologii RAS.

Burykin, Aleksei A. 2001. Malye zhanry evenskogo folklora [Small Genres of Even Folklore]. Saint-Petersburg: Peterburgskoe Vostokovedenie.

Butanayev, Viktor Ya. 1975. Predstavlenia o nebesnyh svetilah v folklore khakasov [Ideas concerning celestial bodies in Khakas folklore]. - Uchenye zapiski Khakasskogo NII yazyka, literatury i istorii. Seria filologicheskaia [Proceedings of the Khakas Institute of Language, Literature and History. Philological series]. Iss. 20, no. 3, s. 231-240.

Carreira, Antonio 1947. Mandingas da Guiné Portuguesa. Bissau: Centro de Estudios da Guiné Portuguesa.

Charnoluski, Vladimir V. 1962. Saamskie skazki [Lapp Folktales]. Moscow: Gosudarstvennoe izdatelstvo khudozhestvennoi literatury.

Chibirov, Liudvig A. 2008. Traditsionnaia duhovnaya kultura osetin [Traditional Spiritual Culture of the Ossetians]. Moscow: Rossiiskaya Politicheskaya Entsiklopedia (ROSSPEN)). 
Choi, In-Hak 1979. A Type Index of Korean Folktales. Seoul: Myong Ji University Publishing.

Chubinski, Pavel P. 1872. Trudy etnografichesko-statisticheskoi ekspeditsii $v$ Zapadno-russki kray. Yugo-zapadny otdel. Materialy i issledovania sobrannye P. P. Chubinskim [Transactions of Ethnograpfic-statistical Expedition to West-Russian Region. Southwestern Department. Materials and Studies of P.P. Chubinski]. Vol. 1. Saint-Petersburg: Imperatorskoe Russkoe Geograficheskoe Obschestvo.

Chuloschnikov, A. P. 1924. Ocherki po istorii kazakh-kirgizskogo naroda $v$ sviazi s obschimi istoricheskimi sudbami drugih tiurkskih plemen [Essays on history of Kazakh-Kirghiz people in relation to common historical lots of other Turkic tribes]. Orenburg: s.e.

Clark, Ella E. 1953. Indian Legends of the Pacific Northwest. Berkeley \& Los Angeles: University of California Press.

Colldén, Lisa 1971. The Traditional Religion of the Sakata. Uppsala: Almqvist \& Wiksells Boktryckeri.

Curtis, Edward S. 1976. The North American Indian. Vol. 19. New York, San Francisco, and London: Johnston Reprinting Corporation.

Dalgat, Uzdiat B. 1972. Geroicheski epos chechentsev i ingushei [Chechen and Ingush Heroic Epics]. Moscow: Nauka.

Davletshin, G. M. 1979. O kosmogonicheskih vozzreniah volzhskih bulgar domongolskogo perioda [On the cosmogonic ideas of Volga Bulgar of the pre-Mongol Period]. - Iz Istorii Tatarskoi Obschestvennoi Mysli, Ed. by Ya. G. Abdullin, Kazan: Institut yazyka, literatury i istorii im. G. Ibragimova Kazanskogo filiala AN SSSR, s. 44-55.

Dennett, Richard E. 1898. Notes on the Folklore of the Fjort. London: The Folk-Lore Society.

Diachkov, Afanasi Y. 1992. Anadyrski kray [Anadyr Region]. - Diachkov A. Y. \& N. A. Zhikharev. Povest' ob Afanasii. Magadan: Magadanskoe knizhnoe izdatel'stvo, pp. 163-267.

Diakonova, Vera P. 1976. Religioznye predstavlenia altaitsev i tuvintsev o prirode i cheloveke [Religion ideas of the Altaians and Tuvinians about nature and man]. - Priroda $i$ Chelovek $v$ Religioznyh Predstavleniyah Narodov Sibiri $i$ Severa, Ed. by I. S. Vdovin. Leningrad: Nauka, s. 268-291.

Dorsey, George A. 1904. The Mythology of the Wichita. Carnegie Institution of Washington, Publication No. 21.

Dorsey, James O. 1895. Kwapa folk-lore. - Journal of American Folklore 8 (28), pp. 130-131.

Driver, Harold E. 1937. Culture element distributions: VI. Southern Sierra Nevada. - University of California Anthropological Records 1(2), pp. 53-154.

Eelsalu, Heino 1993. Rahvaluule mõistatuslik valge põder. Saami astraalmüüt. Keel ja Kirjandus 9, lk 611-616.

Elmendorf, William W. 1960. The Structure of Twana Culture. Pullman: Washington State University. 
Erdödi, József 1968. Finnisch-Ugrische Gestirnnamen. - Annales Universitatis Scientiarum Budapestiensis de R. Eotvos nominatae. Philologica. T. 8. Budapest, S. 105-121.

Erdoes, Richard \& Alfonso Ortiz 1984. American Indian Myths and Legends. New York: Pantheon Books.

Ergis, Georgi U. 1974. Ocherki po yakutskomu folkloru [Essays on Yakut Folklore]. Moscow: Nauka.

Eyzaguirre, Delfín S. 1956. Astronomía Aymara. - Khana 3 (19-20), pp. 82-98.

Fedorovich, Nadia V. 2009. Ukrainska narodna astronomia [Ukrainian Folk Astronomy]. Abstract of Master's Thesis in History. Kiev: Institut mistetsvoznavstva, folkloristiki ta etnologii.

Fortescue, Michael, Steve Jacobson \& Lawrence Kaplan 1994. Comparative Eskimo Dictionary with Aleut Cognates. Fairbanks: Alaska Native Language Center.

Foster, George M. 1944. A summary of Yuki culture. - University of California Anthropological Records 5 (3), pp. 155-244.

Friedberg, Claudine 1973. Reperace et decoupage du temps chez les Bunaq du centre de Timor. - Cahiers de Litterature Orale 6, p. 119-143.

Gamzatov, G. G. \& Uzdiat B. Dalgat 1991. Traditsionny folklor narodov Dagestana [Traditional Folklore of the Peoples of Dagestan]. Moscow: Nauka.

Ganalanian, Aram T. 1965. Armianskie narodnye skazki [Armenian Folk-Tales]. Yerevan: Aiastan.

Garf, Anna L. \& Pavel V. Kuchiyak 1978. Tanzagan - otets altaitsev [Tanzagan, Father of the Altai People]. Moscow: Khudozhestvennaia literatura.

Gibbon, William B. 1964. Asiatic parallels in North American star lore: Ursa Major. - Journal of American Folklore 77 (305), pp. 236-250.

Gibbon, William B. 1972. Asiatic parallels in North American star lore: Milky Way, Pleiades, Orion. - Journal of American Folklore 85 (337), pp. 236-247.

Gładyszowa, Mária 1960. Wiedza ludowa o gwiazdoch. Wroclaw: Zaklad narodovyim ossolińskich.

Gottschilng, Rev. E. 1905. The Bawenda: a sketch of their history and culture.The Journal of the Royal Anthropological Institute of Great Britain and Ireland 35, pp. 376-386.

Graham, David C. 1954. Songs and Stories of the Ch'uang Miao. Washington D.C.: Smithsonian Institution.

Greenlee, Robert F. 1945. Folktales of the Florida Seminole. - Journal of American Folklore 58 (228), pp. 138-144.

Grimm, Jacob 1883. Teutonic Mythology. London: George Bell \& Sons.

Gundel, Wilhelm 1922. Sterne und Sternbilder im Glauben des Altertums und der Neuzeit. Bonn, Leipzig: Kurt Schroeder Verlag.

Henninger, Joseph 1954. Über Sternkunde und Sternkult in Nord- und Zentralarabien. - Zeitschrift für Ethnologie 79 (1), S. 82-117.

Hines, Donald M. 1996. Celilo Tales. Wasco myths, legends, tales of magic and the marvelous. Issaquah, WA: Great Eagle Publishing. 
Hirschberg, Walter 1929. Die Plejaden in Africa und ihre Beziehung zum Bodenbau. - Zeitschrift für Ethnologie 61 (4-6), S. 321-337.

Hollis, A. C. 1909. The Nandi. Their Language and Folklore. Oxford: Clarendon Press.

Holmberg, Uno 1927. The Mythology of All Races. Vol. 4. Finno-Ugric, Siberian. Boston: Archaeological Institute of America, Marshall Jones Co.

Ivanov, Viacheslav Vs. 1977. Luna, upavshaia s neba. Drevniaya literatura Maloi Azii [Moon that Fell from the Sky. Ancient Literature of Asia Minor]. Moscow: Khudozhestvennaia literatura.

Jankovich, Nenad 1951. Astronomia u predan'ima, obichaiima $i$ umotvorinama srba [Astronomy in Legends, Customs, and Folklore of the Serbs]. Beograd: Srpska Akademiya Nauka.

Joanidi, A. L. 1985. Legendy ta perekazi [Legends and Folktales]. Kiev: Naukova dumka.

Jones, William 1907. Fox Texts. Leyden: American Ethnological Society.

Junod, Henri-Alexandre 1927. The Life of a South African Tribe. Vol. 2. London: Macmillan \& Co.

Jurtubaev, Mahti 1991. Drevnie verovania balkartsev i karachaevtsev [Ancient Beliefs of Balkar and Karachai People]. Nalchik: Elbrus.

Kabakova, Galina 1998. Aux origines du mondes. Contes et légendes de France. Paris: Flies France.

Karpenko, Yuri O. 1992. Astronomia i poganski svit shidnyh slovian [Astronomy and pagan worldview of Western Slavs]. - Onomastika Ukrainy pershogo tysiachelettia nashoi yery. Kiev: Naukova dumka, s. 186-200.

Kharuzin, Nikolai 1890. Russikie Lopari [Russian Lapps]. Moscow: Imperatorskoe obschestvo liubitelei yestestvoznania, antropologii i etnografii.

Khvartskia, I. 1994. Abkhazskie skazki i legendy [Abkhazian Folktales and Legends]. Moscow: DI-DIK.

Kitao, Kouichi 2002. Star Lore of Japan. The Starscape of a People. Amherst, Mass.: Ama River Publishing.

Koekemoer, Gerhardus P. 2007. Lightning Design in an African Content. Submitted in partial fulfillment of the requirements of for the degree of Magister technologiae: performing arts technology. Department of Entertainment Technology, Faculty of the Arts, Tshwane University of Technology. Pretoria a.o.: Tshwane University of Technology.

Kokov, Jamaldin N. 1980. Iz adygeiskoi kosmogonii [From Adyg cosmogony]. Onomastika Kavkaza. Ordzhonikidze: Severo-osetinski gos. universitet, s. 171-172.

Kolchin, A. 1899. Verovania krestian Tulskoi gubernii [Beliefs of the peasants of Tula Province]. - Etnograficheskoe obozrenie 42 (3), s. 1-60.

Kozmin, Artem V. 2008. Sozvezdie Bolshoi Medveditsy v mongolskoi traditsii [Constellation of Ursa Major in Mongolian tradition]. - Zhivaia starina 3, s. 1720.

Krappe, Alexander H. 1930. The Science of Folk-Lore. London: Methuen \& Co.

Krappe, Alexander H. 1938. La Genèse des Mythes. Paris: Payot. 
Kreinovich, Yeruhim A. 1929. Ocherk kosmogonicheskih predstavlenii gilyak ostrova Sakhalin [A review of cosmogonic ideas of the Gilyak of Sakhalin Island]. Etnografia 1, s. 78-102.

Kroeber, Alfred L. 1907. Gros Ventre myths and tales. - Anthropological Papers of the American Museum of Natural History 1 (3), pp. 55-139.

Kronenberg, Andreas 1958. Die Teda von Tibesti. Horn - Wien: Verlag Ferdinand Berger.

Kuftin, Boris A. 1916. Kalendar i pervobytnaia astronomia kirgiz-kaisatskogo naroda [Calendar and primitive astronomy of Kirghiz-Kaisak people]. Etnograficheskoe obozrenie 111-112 (3-4), s. 123-155.

Kuperjanov, Andres 2003. Eesti taevas. Tartu: Eesti Folkloori Instituut.

Kuperjanov, Andres 2010. The Churl's Wagon. - Folklore: Electronic Journal of Folklore 44, pp. 51-60.

Kurtik, Gennady E. 2007. Zvezdnoe nebo drevnei Mesopotamii [Star sky of Ancient Mesopotamia]. Saint-Petersburg: Aleteia.

Lagercrantz, Sture 1952. The Milky Way in Africa. - Ethnos 17, pp. 64-72.

Laman, Karl 1962. The Kongo III. Uppsala: Almqvist \& Wiksells Boktryckeri.

Lankford, George E. 2007. Reachable Stars. Patterns in the Ethnoastronomy of Eastern North America. Tuscaloosa: The University of Alabama Press.

Lashkarbekov, Bogsho 2008. Akidahon kadimii mardum doir ba chirmhon va digar hodisahoi koinot. Nebesa $i$ svetila $v$ narodnom predstavlenii [Sky and celestial bodies in the folk worldview]. Manuscript.

László, Gáldi 1975. Orosz-magyar kéziszótár. Budapest: Akadémiai kiadó.

Lehner, Stephan 1931. Die Naturanschauung der Eingebornen im N.O. New-Guineas. - Baessler-Archiv 14 (4), pp. 105-122.

Lindblom, Gerhard 1920. The Akamba in British East Africa. Uppsala: Appelbergs Boktryckeri Aktiebolag.

Litvinski, Boris A. 2004. Nuristantsy [The Nuristani]. - Mify i Religii Mira. Ed. by S. Yu. Nekliudov. Moscow: Russian University of Humanities, s. 121-127.

Loorits, Oskar 1926. Livische Märchen- und Sagenvarianten. Helsinki: Suomalainen Tiedeakatemia.

Loorits, Oskar 2000. Liivi rahva usund IV. Tartu: Eesti Keele Instituudi rahvausundi töörühma väljaanne.

Lopatin, Ivan A. 1922. Goldy amurskie, ussuriiskie i sungariiskie. Opyt etnograficheskogo issledovania [Amur, Ussuri and Sungari Golds. Essay of Ethnoghraphic Study]. Vladivostok: Obschestvo izuchenia Amurskogo kraia vladivostokskogo otdelenia priamurskogo otdela Russkogo Geograficheskogo Obschestva.

Lowie, Robert H. 1918. Myths and Traditions of the Crow Indians. New York: American Museum of Natural History.

Lukina, Nadezhda V. 1990. Mify, predania, skazki khantovi mansi [Myths, Legends, Tales of the Khanty and Mansi]. Moscow: Nauka.

Lundmark, Bo 1982. Sol- och månkult samt astrala och celesta förestäningar bland samerna. Umea: Västerbotens Museum. 
Maaß, Alfred 1921. Sterne und Sternbilder im malaischen Archipel. - Zeitschrift für Ethnologie 52 (1), S. 38-63.

Macdonald, James 1891. Manners, customs, superstitions, and religions of South African tribes. - The Journal of the Royal Anthropological Institute of Great Britain and Ireland 20, pp. 113-140.

MacDonald, John 1998. The Arctic Sky: Inuit Astronomy, Star Lore, and Legend. Toronto: Royal Ontario Museum, Nunavir Research Institute.

Magaña, Edmundo 1983. Star myths of the Kaliña (Carib) Indians of Surinam. Latin American Indian Literatures 7 (1), pp. 20-37.

Magaña, Edmundo 1988. Orion y la Mujer Pléyades. Simbolismo Astronómico de los Índios Kaliña de Surinam. Amsterdam: Centro de estudios y documentación latinoamericanos.

Magaña, Edmundo, \& Fabiola Jara 1982. The Carib sky. - Journal de la Société des Américanistes 68, pp. 105-132.

Mándoki, László 1965. Straw path. Data on the spread and the origin of the Mediterranean name type of Via Lactea. - Acta Ethnographica 14 (1-2), pp. 117139.

Matičetov, Milko 1973. Zvesdna imena in izročila o zvezdah med slovenci. - Traditiones. Zbornik Instituta za Slovensko Narodopisie (Ljubljana) 2, s. 43-90.

Mazin, Anatoli I. 1984. Traditsionnye verovania i obriady evenkov-orochonov (konets $X I X$ - nachalo XX v.) [Traditional Believes and Rituals of the Orochon Evenks (late XIX - early XX centuries]. Novosibirsk: Nauka.

McCleary, Timothy 1997. The Stars We Know. Crow Indians Astronomy and Lifeways. Prospect Hights, Ill.: Waveland Press.

Mercier, H. Juan M. 1979. Nosotros los Napu-Runas: Napu Runapa Rimay, Mitos e Historia. Iquitos: Publicaciones CETA.

Meretukov, K. Kh. 1980. O nekotoryh kosmonimah adygeiskogo yazyka [On some cosmonymic terms of Adyg language]. - Onomastika Kavkaza. Ordzhonikidze: Ministerstvo Vysshego i Srednego Spetsialnogo Obrazovania RSFSR, a.o, s. $173-176$.

Michelson, Truman 1911. Piegan tales. - Journal of American Folklore 24, pp. $238-248$.

Mickiewicz, Adam 1955. Pan Tadeusz. Tr. to Russian by S. Mar (Aksenova). Adam Mickiewicz. Selected works in 2 vols. Vol. 2. Moscow: Gos. izdatelstvo khudozhestvennoi literatury, s. 277-570.

Miller, Vsevolod 1882. Osetinskie etudy [The Ossetian Essays]. Part 2. Moscow: Moskovski universitet.

Mladenova, Darina 2006. Zvezdnoto nebe nad nas. Etnolingvistichno issledovene na balkanskite narodni astronomi. [Star Sky above Us. Ethnolinguistic Study of the Balkan Folk Astronomies]. Sofia: Prof. Marin Drinov.

Monroe, Jean Guard \& Ray A. Williamson 1987. They Dance in the Sky. Native American Star Myths. Boston: Houghton Mifflin Co.

Moshkov, Valentin A. 1901. Gagauzy Benderskogo uyezda [The Gagauz of Bender District]. - Etnograficheskoe obozrenie 51 (4), s. 1-80. 
Munkácsi, Bernhard (Bernát) 1908. Die Weltgottheiten der Wogulischen Mythologie. - Revue orientale pour les études ouralo-altaïques 9 (3), S. 206277.

Munkácsi, Bernhard (Bernát) 1995. Vogul Folklore. Budapest: Akadémiai Kiadó; Los Angeles: International Society for Trans-Oceanic Research.

Münzel, Mark 1973. Erzählungen der Kamayura. Wiesbaden: Steiner.

Nadrshina, Fanuza 1985. Bashkirskie predania i legendy [Bashkir Traditions and Legends]. Ufa: Bashkirskoe knizhnoe izdatelstvo.

Nassen-Bayer \& Kevin Stuart 1992. Mongol creation stories: man, Mongol tribes, the natural world, and Mongol deities. - Asian Folklore Studies 51 (2), pp. 323-334.

Niebrzegowska, Stanisława 1999. Gwiazdy w ludowym jęzkowym obrazie świata. Językowy obraz świta. Lublin: Wydawnictwo Uniwersytetu Marie CurieSkłodowskiej, s. 137-154.

Nikonov, Vladimir A. 1973. Kosmonimia Povolzhia [Cosmonymy of Volga Region]. Onomastika Povolzhia. Ufa: Bashkir branch of Academy of Sciences of the USSR, s. 373-381.

Nikonov, Vladimir A. 1980. Materialy po kosmonimike Srednei Azii [Materials on the Central Asian cosmonimics]. - Onomastika Srednei Azii. Frunze: Ilim, s. $290-306$.

Nilsson, Martin P. 1920. Primitive Time-reckoning. Acta societatis humanorum litterarum lundensis 1 . Lund.

Ochirova, A.M. 1991. Kalmytskaia kosmogonia [The Kalmyk cosmogony]. - Onomastika Povolzhia. Moscow: Academy of Sciences of the USSR, s. 192-198.

Okladnikov, Alexei P. 1950. Neolit i bronzovy vek Pribaikalia [Neolithic and Bronze Age of cis-Baikal Area]. Moscow and Leningrad: Izdatelstvo Akademii Nauk SSSR.

Osharov, Mikhail I. 1936. Severnye skazki [Northern Folktales]. Moscow: s.e.

Pâques, Viviana 1964. L'arbre cosmique dans la pensée populaire et dans la vie quotidienne du nord-ouest africain. Paris: Institut d'Ethnologie, Musée de l'Homme.

Parsons, Elsie C. 1929. Kiowa Tales. New York: the American Folklore Society.

Pezhemski, V. S. 1936. Dve legendy yerbogachenskih evenkov [Two legends of Yerbogachen Evenki]. - Materialy po evenkiiskomu (tungusskomu) folkloru. Iss. 1. Compiled by G. M. Vasilevich. Leningrad: Izdatelstvo intituta narodov Severa TsIK SSSR, pp. 272-275.

Popov, Rachko 2003. Sledi ot kulta k'm mechkata v vyaravaniyata i obichaite na balkanskite narodi [Traces of bear cult in believes and customs of Balkan peoples]. - Rastitelniyat $i$ zhivotinskiyat svyat $v$ traditsionnata kultura na B'lgarite. Sofia: Etnografski institut s muzei, s. 260-275.

Porsanger, Elena 2005. Astral mythology. - The Saami. A cultural encyclopaedia. Ed. by Ulla-Maija Kulonen, Irja Seurujärvi-Kari, Risto Pulkkinen. Helsinki: Vammala, pp. 26-27.

Reed, Alexander W. 1999. Maori Myths \& Legendary Tales. Aukland, Sydney, London, Cape Town: New Holland Publishers. 
Pentikäinen, Juha 1997. Die Mythologie der Saamen. Berlin: Reinhold Schletzer Verlag.

Podmaskin, Vladimir V. 1991. Duhovnaia kultura udegeitsev [Spiritual Culture of the Udeghe]. Vladivostok: Izdatelstvo Dalnevostochnogo universiteta.

Potanin, Grigori N. 1881. Ocherki severo-zapadnoi Mongolii. Vypusk II. Materialy etnograficheskie [Northwest Mongolia Essays. Ethnographic Materials]. Saint-Petersburg: tipografia V. Kirshbauma.

Potanin, Grigori N. 1883. Ocherki severo-zapadnoi Mongolii. Vypusk IV. Materialy etnograficheskie [Northwest Mongolia Essays. Ethnographic Materials]. Saint-Petersburg: tipografia V. Kirshbauma.

Potanin, Grigori N. 1893. Tangutsko-tibetskaya okraina Kitaya $i$ Tsentralnaia Mongolia [The Tangut-Tibetan Borderlands of China and Central Mongolia]. Vol. 2. Saint-Petersburg: tipografia A. S. Suvorina.

Potanin, Grigori N. 1899. Vostochnye motivy v srednevekovom yevropeiskom epose [Eastern Motifs in Medieval European Epics]. Moscow: Imperatorskoe obschestvo liubiteley yestestvoznania, antropologii i etnografii.

Potanin, Grigori N. 1919. Mongol'skie skazki i predania [Mongol folktales and traditions]. - Zapiski Semipalatinskogo podotdela Zapadno-sibirskogo otdela Russ. Geogr. obschestva, iss. 13, s. 1-97.

Prokofieva, Yekaterina D. 1961. Predstavlenia selkupskih shamanov o mire (po risunkam i akvareliam selkupov) [Ideas of the Selkup shamans about the world (according to Selkup drawings and water-colours)]. - Sbornik Museia Antropologii i Etnografii 20, pp 54-74.

Prüller, Paul-Egon 1961. Eesti rahvaastronoomia. - Eesti Loodus 4, lk 291-294; 6, lk 354-358.

Radlov, Vassili V. 1907. Obraztsy narodnoi literatury tiurkskih plemen [Samples of the Folk Literature of the Turkic Tribes]. Part IX. Saint-Petersburg: Imperatorskaia Akademia Nauk.

Rassadin, Valentin I. 1996. Legendy, skazki i pesni sedogo Sayana. Tofalarski folklor [Legends, Folktales and Songs of Old Sayan. The Tofa Folklor]. Irkutsk: Komitet po kulture Irkutskoi oblastnoi administratsii, Oblastnoi tsentr tvorchestva i dosuga.

Reagan, Albert B. 1927. Notes on Jemez ethnography. - American Anthropologist 29, pp. 719-728.

Reichel-Dolmatoff, Gerardo 1982. Astronomical models of social behavior among some Indians of Colombia. - Ethnoastronomy and Archaeoastronomy in the American Tropics. Ed. by Anthony E. Aveni and Gary Urton. New York: New York Academy of Sciences, pp. 165-181.

Rivera de Bianchi, Mabel 1973. Mitología de los pueblos del Chaco, según visión de los autores de los siglos XVII y XVIII. - América Indígena 23 (3), pp. 695733.

Rizvanov, Zabit \& Rizvan Rizvanov 1990. Istoria lezgin (kratki nauchno-populiarny ochek) [History of Lezgin (A short popular essay)]. Mahachkala: Obschestvo knigoliubov. 
Robiou-Lamarche, Sebastián 1986. Ida y vuelta a Guanín, un ensayo sobre la cosmovisión taína. - Myths and the Imaginary in the New World. Ed. by Edmundo Magaña and Peter Mason. Dordrecht, The Netherlands: Centro de estudios y documentación latinoamericanos, pp. 459-498.

Rombandeeva, Yevdokia I. 2005. Mify, skazki, predania mansi (vogulov) [Myths. Folktales, Legends of Mansi (Vogul)]. Moscow and Novosibirsk: Nauka.

Roth, Walter E. 1915. An Inquiry into the Animism and Folklore of the Guiana Indians. - 30th Annual Report of the Bureau of Ethnology to the Secretary of the Smithsonian Institution (1908-1909). Washington D.C.: Government Printing Office, pp. 26-745.

Rustige, Rona 1988. Tyendinaga Tales. Kingston \& Montreal: McGill-Queen's University Press.

Rut, Maria E. 1987. Russkaia narodnaia astronomia [Russian Folk Astronomy]. Sverdlovsk: Uralski Gos. Universitet.

Sadalova, Tamara M. 2002. Altaiskie narodnye skazki [Altai Folktales]. Novosibirsk: Nauka.

Samdan, Zoya B. 1994. Tuvinskie narodnye skazki [Tuvinian Folktales]. Novosibirsk: Nauka.

San'ko, S. 2004a. Kasary. - Belaruskaia mifalogia: entsyklopedychny slounik. Minsk: Belarus, s. 236.

San'ko, S. 2004b. Sahachy. - Belaruskaia mifalogia: entsyklopedychny slounik. Minsk: Belarus, s. 453.

Sem, Tatiana Y. 1990. Traditsionnye predstavlenia negidaltsev o mire [Traditional worldview of the Negidals]. - Religiovedcheskie issledovania $v$ etnograficheskih muzeyah, Ed. by B. V. Ivanov. Leningrad: Gosudarstvenny Muzei Etnografii, s. 90-113.

Semenov, Viktor A. 1994. O nekotoryh sposobah organizatsii i opisania kosmosa narodami uralskoi yazykovoi sem'i [On some ways of organization and description of cosmos by the Uralic people]. - Smert' kak fenomen kul'tury. Ed. by V. A. Semenov. Syktyvkar: Syktyvkarski gos. universitet, s. 115-121.

Seroshevski, Vatslav L. 1896. Yakuty. Opyt etnograficheskogo issledovania [The Yakuts. Essay of Ethnographic Study]. Vol. 1. Saint-Petersburg: Imperatorskoe Russkoe Geograficheskoe Obschestvo.

Shkalina, Galina E. 2003. Traditsionnaia kultura naroda mari [Traditional Culture of Mari People]. Yoshkar-Ola: Mariiskoe knizhnoe izdatel'stvo.

Shrestha, Krishna P. 1996. Mify i legendy Nepala [Myths and Legends of Nepal]. Moscow: I. M. Shrestha.

Sicard, Harald von 1966. Karanga stars. - Southern Rhodesia Native Affairs Department Annual 9 (3), pp. 142-165.

Simms, Stephen C. 1904. Traditions of the Sarcee Indians. - Journal of American Folklore 17, pp. 180-182.

Sirotkin, Mikhail Y. \& M. I. Ivanov 1970. Chuvashi. Etnograficheskoe issledovanie [the Chuvash. Study in Ethnography]. Part. 2. Cheboksary: Knizhnoe izdatelstvo. 
Skorodumova, Lidia G. 2003. Skazki i mify Mongolii [Folktales and Myths of Mongolia]. Ulaanbaatar: Monsudar.

Šmitek, Zmago 2001. Astral symbolism on the pre-Romanesque relief in Keutschch (Hodiše). - Studia mythologica slavica 4, pp. 119-139.

Smith, David L. 1997. Folklore of the Winnebago Tribe. Norman: University of Oklahoma Press.

Smith, Marian W. 1940. The Puyallup-Nisqually. New York: Columbia University Press.

Smoliak, Anna V. 1976. Predstavlenia nanaitsev o mire. - Priroda $i$ Chelovek v Religioznyh Predstavleniyah Narodov Sibiri i Severa. Leningrad: Nauka, pp. 129-160.

Smoliak, Anna V. 1991. Shaman: lichnost, funktsii, mirovozzrenie (narody Nizhnego Amura) [Shaman: Personality, Functions, Worldview (Lower Amur Peoples)]. Moscow: Nauka.

Spence, Lewis 1985. North American Indians. New York: Avenel Books.

Spieth, Jakob 1906. Die Ewe-Stämme. Material zur Kunde des Ewe-Volkes in DeutschTogo. Berlin: Dietrich Reimer.

Stepanian, Nonna S. 1971. Dekorativnoe iskusstvo srednevekovoi Armenii [Decorative Art of Medieval Armenia]. Leningrad: Avrora.

Stoinev, Anani 2006. B'lgarska mitologia [Bulgarian Mythology]. Sofia: Zakhari Stoyanov.

Studstill, John D. 1984. Les Desseins d’Arc-en-ciel: Épopée chez les Luba du Zaüre. Paris: Éditions du Centre Nacional de la Recherche Scientifique.

Sviatski, Daniil O. 1961. Ocherki istorii astronomii v Drevnei Rusi [Essays of the history of astronomy in Ancient Russia]. - Istoriko-astronomicherskie issledovania. Iss. 7. Moscow: Gosudarstvennoe izdatel'stvo fiziko-matematicheskoi literatury, s. 75-128.

Syma Tsyan 1986. Istoricheskie Zapiski („Shi Tsi“) [Sima Ch’ien. Historical Records („Shih Chi“)]. Translated from Chinese and commented on by R. V. Vyatkin and V. S. Taskin. Vol. 4. Moscow: Nauka.

Talbot, P. Amaury 1932. Tribes of the Niger Delta. London: The Sheldon Press.

Teit, James A. 1900. The Thompson Indians of British Columbia. New York: Jesup North Pacific Expedition.

Temkin, Eduard N. \& Vladimir G. Erman 1982. Mify drevnei Indii [Myths of Ancient India]. Moscow: Nauka.

Tessmann, Günter 1923. Die Bubi auf Fernando Poo. Völkerkundliche Einzelbeschreibyng eines westafrikanischen Negerstammes. Hagen, Darmstadt: Folkwang-Verlag.

Tessmann, Günter 1934. Die Bafia und die Kultur der Mittelkamerun-Bantu. Stuttgart: Strecker und Schröder.

Thomas, Northcote W. 1919. Nigerian notes. Astronomy. - Man 19 (91-92), pp. 179-183.

Tiurina, Ruslana Y. 1972. Leksika prirody $v$ russkih starozhilcheskih govorah Srednego Priobia [Vocabulary of nature in Russian old resident dialects of Middle Ob area]. Master's thesis in philology. Tomsk: Tomski gos. universitet. 
Tuchkova, Natalia A. 2002. „Epos ob Itte“v yuzhnoselkupskom areale [„Itte epics“ in Southern Selkup area]. - Muzeinye fondy i ekspozitsii v nauchno-obrazovatelnom protsesse. Tomsk: Izdatelstvo Tomskogo gos. universiteta, s. 93108.

Ushakov, G. A. 2001. Ostrov metelei [Island of Snow-storms]. Saint-Petersburg: Gidrometeoizdat.

Vaiškūnas, Jonas 1999. Etnoastronomia litewska. - Etnolingwistika 11, p. 165175.

Vaiškūnas, Jonas 2004. Narodnaia astronomia belorussko-litovskogo pogranichia [Folk astronomy of Belorussian-Lithuanian borderlands]. -Balto-slavianskie issledovania. Iss. 16. Moscow: Indrik, s. 168-179.

Vasilevich, Glafira M. 1959. Rannie predstavlenia o mire u evenkov (materialy) [Early ideas about the world among the Evenki (the materials)]. - Trudy Instituta Etnografii 51, s. 157-192.

Vassilkov, Yaroslav V. \& Svetlana L. Neveleva 1987. Mahabharata. Kniga III, Lesnaya [Mahabharata. Book III. The Forest Book (Aranyakaparva)]. Tr. from Sanskrit, with introduction and notes by Y. V. Vassilkov and S. L. Neveleva. Moscow: Nauka.

Vickers, William T. 1989. Los Sionas y Secoyas. Quito: Ediciones Abya-Yala.

Vieira, Vincent 2009. The constellation of Orion and the Cosmic Hunt in Equatorical Africa. - Anthropos 104, pp. 558-561.

Volpati, Carlo 1932. Nomi romanzi degli astri Sirio, Orione, le Pleiadi e le Jadi. Zeitschrift für romanische Philologie 52, S. 151-211.

Volpati, Carlo 1933a. Nomi romanzi delle Orse, Boote, Cigno e altre constellazioni. Zeitschrift für romanische Philologie 53, S. 449-507.

Volpati, Carlo 1933b. Nomi romanzi della Via Lattea. - Revue de linguistique romane 9 , p. 1-51.

Vorobiev, Nikolai I. \& G. M. Khisamutdinov 1967. Tatary Srednego Povolzhia $i$ Priuralia [The Tatars of Middle Volga and cis-Ural Region]. Moscow: Nauka.

Voskoboinikov, Mikhail G. 1958. Folklor evenkov Buryatii [Folklore of Buryatia Evenks]. Ulan-Ude: Buryatskoe knizhnoe izdatel'stvo.

Waterman, Patricia P. 1987. A Tale-Type Index of Australian Aboriginal Oral Narratives. Helsinki: Suomalainen Tiedeakatemia.

Wavrin, Robert 1979. Mythologie, Rites et Sorcellerie des Indiens de l'Amazonie. Monaco: Édition du Rocher.

Weeks, John H. 1909. Notes on some customs of the Lower Congo people. - FolkLore 20 (1, 4), pp. 32-63, 209-210.

Werner, Alice 1912. Note on Bantu star-names. - Man 12, pp. 193-196.

Wilbert, Johannes \& Karin Simoneau 1982a. Folk Literature of the Mataco Indians. Los Angeles: UCLA Latin American Center Publications, University of California. 
Wilbert, Johannes \& Karin Simoneau 1982b. Folk Literature of the Toba Indians, Vol. 1. Los Angeles: UCLA Latin American Center Publications, University of California.

Wilbert, Johannes \& Karin Simoneau 1985. Folk Literature of the Chorote Indians, Los Angeles: UCLA Latin American Center Publications, University of California.

Wilbert, Johannes \& Karin Simoneau 1988. Folk Literature of the Mocov7 Indians, Los Angeles: UCLA Latin American Center Publications, University of California.

Wilbert, Johannes \& Karin Simoneau 1989. Folk Literature of the Toba Indians, Vol. 2. Los Angeles: UCLA Latin American Center Publications, University of California.

Williamson, Robert W. 1933. Religious and Cosmic Beliefs of Central Polynesia. Vol. 1. Cambridge: University Press.

Wissler, Clark \& D. C. Duvall 1908. Mythology of the Blackfoot Indians. New York: American Museum of Natural History.

Yermakov, Viktor I. 1988. Tanchami. Skazki narodov Severa [Tanchami. Folktales of the peoples of the North]. Krasnoyarsk: knizhnoe izdatel'stvo.

Yuhma, Mishshi N. 1980. Zametki o chuvashskoi kosmonimii [Notes on Chuvash cosmonymy]. - Onomastika Vostoka. Moscow: Nauka, s. 264-269.

Znoiko, O. P. 1989. Mify Kyivskoi zemli ta podii starodauni [Myths of Kiev Land and Events of Old Time]. Kiev: Molod.

Zolotnitski, Nikolai I. 1874. Otryvki iz chuvashsko-russkogo slovaria. No. 14. Chubashskie nazvania Boga, neba $i$ svetil nebesnyh [Fragments from Chuvash-Russian Dictionary. No. 14. Chuvash names for God, sky and sky luminaries]. Kazan: gubernskaia tipografia.

\section{Kokkuvõte}

\section{SEITSE VENDA JA KOSMILINE JAHT: EUROOPA TAEVAS ENNEMUISTE}

Selleks, et rekonstrueerida varase Euroopa tähistaeva-uskumusi, tuleb vaadata uskumusi taevakehade kohta, mida tuntakse kogu põhjapoolkeral. Nende hulgas on lisaks ainukordsetele ka mitmed uskumusi, mis on tuntud Aafrikast kuni Põhja-Ameerikani. Kõige laiemalt nii Euraasias kui Põhja-Ameerikas levinud uskumuse kohaselt on Suur Vanker seitse meest, kusjuures Alcor on koer või noorem ehk nõrgem isik (poiss, tüdruk, noor naine). See uskumus peab olema levinud üle Euraasia parasvöötme hiljemalt paloeliitikumi lõpuks ning saabunud Põhja-Ameerika tasandikele Lõuna-Siberist. Kosmilise jahi müüt ning Orioni vöö tõlgendamine selle kontekstis on tõenäoliselt samuti tekkinud kusagil Kesk-Euraasias ning sealt levinud Põhja-Ameerikasse ning Aafrikasse. Nende uskumuste päritolu Aafrikast ei ole täielikult välistatud, kuid sellisel juhul tuleks oleta- 
da, et mitte ainult koer jahi osalisena ei ole hilisem lisand (Aafrikas polnud koeri enne holotseeni), vaid ka kõnealune motiiv levis Aafrikast MandriEuroopasse ning see juhtus enne Ameerika asustamist. See on küllalt ebatõenäoline, kuna sellest ajastust pole teada ühtki teist usaldusväärset Aafrika ja Mandri-Euraasia paralleeli. Teadaolevad motiivid, mis on levinud nii Euraasia kui Aafrika kultuurides, on hõlpsamini tõlgendatavad Aasiast Aafrikasse tagasirändamise tulemusena (Berezkin 2009a; 2009b).

Need Euraasia alad, kus Suure Vankri peamised tähed on tuntud kui seitse meest ning kus Orioni kolm tähte on tuntud kui kolm noolest lastud sõralist (harva üks sõraline), on suuresti kattuvad, Ameerikas aga mitte. Orioni vöö on Kosmilise Jahi kontekstis laialt levinud Ameerika edelaosas, kuid seitsme mehe motiiv on tuntud Kesk- ja Suurtasandikul ning vaid üksikuid teateid on Kirde-Ameerikast. Koos esinevad need motiivid vaid Wichita ja Gros Ventre'i piirkonnas. Selline kujutelmade piirkondliku leviku erinevus Aasias ning Ameerikas vajab seletust, mida ma praegu ei suuda pakkuda.

Arvatavasti nähti mesoliitikumi ajastul Euroopa parasvöötme aladel Suurt Vankrit kui seitset meest, kuid tõenäoliselt ka kui looma, eelkõige karu. Nende kahe kujutelma omavahelised seosed on ebaselged. Jenissei ümbruse tõlgendus Suurest Vankrist kui kolmest jahimehest ning saakloomast (põder) tundub olevat nende kahe kombinatsioon. Kui Kosmilist Jahti mesoliitikumiaegses Euroopas üldse tunti, siis ilmselt Orioniga seotult. Loode-Euroopa alade uskumuste põhjalik rekonstruktsioon on sisuliselt võimatu, kuna andmed piirkondlikest rahvalikest kosmonüümidest on liialt napid. Saamide eepiline ning eshatolootiline Kosmilise Jahi kujutelm on unikaalne. Kuna sellesse on kaasatud Orion, Kassiopeia ning Plejaadid, ei leia me paralleele mitte lõunapoolsest Euroopast, vaid idapoolsetelt arktilistelt rahvastelt nagu nganassaanid, põhja-jakuudid, paleoasiaadid, eskimod ja eriti tšuktši ja tšukotka jupikid (Bogoras 1939: 25-29; Ushakov 2001: 172).

Uskumused Plejaadidest kui kanast tibudega ning Orionist kui põllutööriistadest, saagikoristajatest, koogust või kaalust ei saa pärineda varasemast perioodist kui neoliitikum. Kana-kujutelm levis arvatavasti KaguAasiast pärast kogu mandrit hõlmava suhtlusvõrgustiku teket ning sama võib põhjendatult oletada adra-kujutelma kohta. Paralleelid niitjate, kootide, rehaga jmt näivad olevat kohalikud väljamõeldised, mis võivad pärineda esimeste Euroopa põllumajanduskultuuride tekke ajast, kuid sama hästi olla ka palju hilisemat päritolu. Koogu ja kaalude kujutelmad võivad olla hilisem islami mõju ning see teema vajaks edasist uurimist.

MÄRKSÕNAD: kosmilise jahi müüt, kosmonüümid, Suur Vanker, Orion, Plejaadid, rahvastiku ränne 
